US Army Corps

of Engineers ${ }_{\circledast}$

Engineer Research and

Development Center
INNOVATIVE SOLUTIONS

for a safer, better world

Engineering for Polar Operations, Logistics, and Research (EPOLAR)

\title{
The Potential Risks and Future Impact of a Large Leverett Glacier Crevasse along the South Pole Traverse (SPoT)
}

John M. Fegyveresi

October 2017

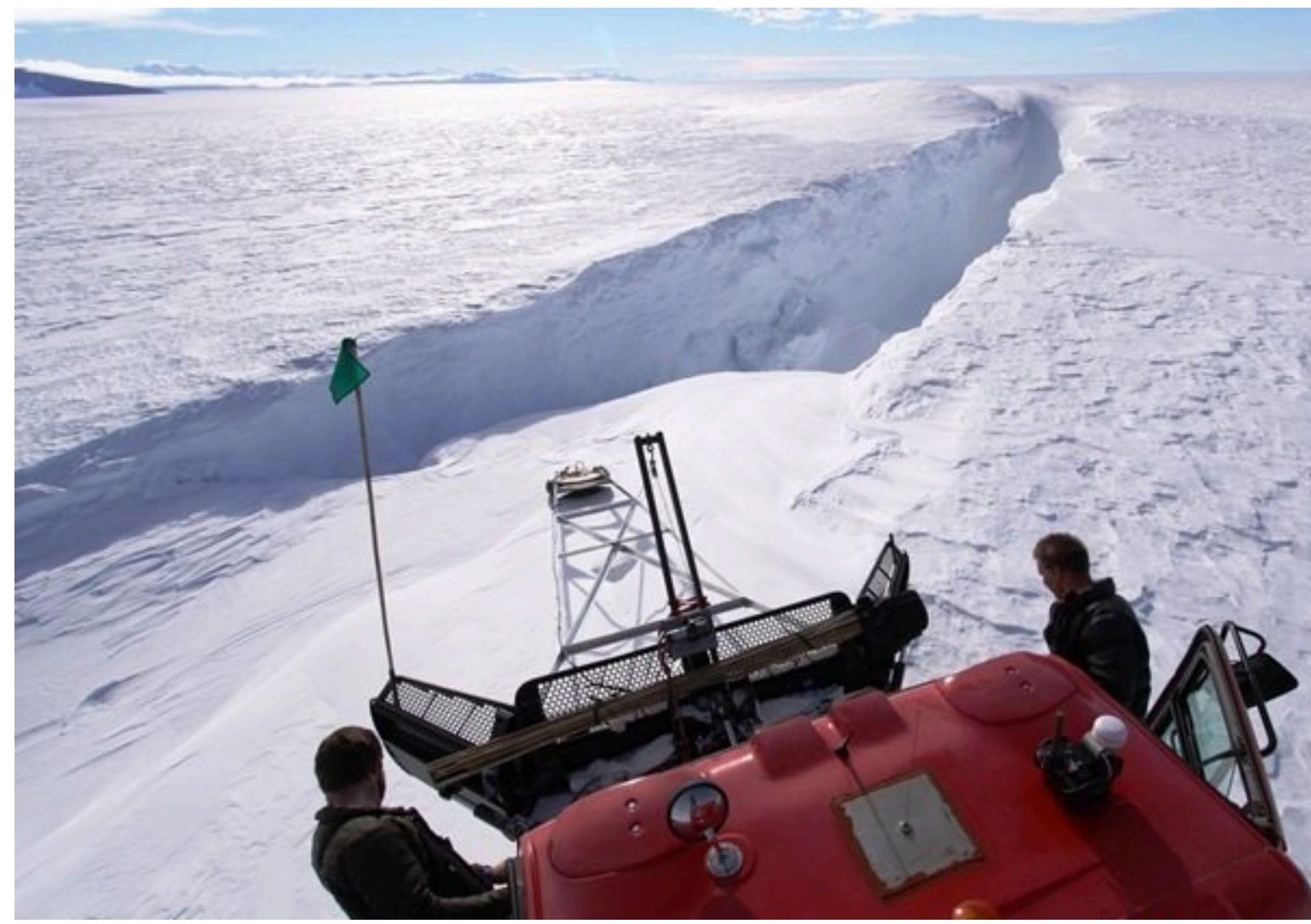

Photograph by David Weimer 
The U.S. Army Engineer Research and Development Center (ERDC) solves the nation's toughest engineering and environmental challenges. ERDC develops innovative solutions in civil and military engineering, geospatial sciences, water resources, and environmental sciences for the Army, the Department of Defense, civilian agencies, and our nation's public good. Find out more at www.erdc.usace.army.mil.

To search for other technical reports published by ERDC, visit the ERDC online library at http://acwc.sdp.sirsi.net/client/default. 


\section{The Potential Risks and Future Impact of a Large Leverett Glacier Crevasse along the South Pole Traverse (SPoT)}

John M. Fegyveresi

U.S. Army Engineer Research and Development Center (ERDC)

Cold Regions Research and Engineering Laboratory (CRREL)

72 Lyme Road

Hanover, NH 03755-1290

Final Report

Approved for public release; distribution is unlimited.

Prepared for National Science Foundation, Office of Polar Programs

Antarctic Infrastructure and Logistics

2415 Eisenhower Avenue

Alexandria, VA 22314

Under Engineering for Polar Operations, Logistics, and Research (EPOLAR)

EP-ANT-16-26, “The Potential Risks and Future Impact of a Large Leverett Glacier Crevasse along the South Pole Traverse (SPoT)" 


\section{Abstract}

In December 2013, the inbound South Pole Traverse (SPoT) encountered a large (approximately $15 \mathrm{~m} \times 4 \mathrm{~km}$ ) open crevasse at the bottom of Leverett Glacier near the traverse route. A crevasse of this size so close to the traverse route could impede future traverses, resulting in significant delays or reroutes, and could pose a significant safety hazard to the SPoT personnel, vehicles, and equipment should it grow or migrate. These risks are difficult to quantify as the glaciological and meteorological setting around Leverett Glacier is particularly dynamic. The uncertainty estimates associated with the possible future growth of the crevasse are thus not well constrained.

This report presents a compiled time-series analysis of satellite-derived multispectral imagery, satellite-derived ice-velocity data, and groundbased meteorological data in an effort to determine the timing and dynamics related to the appearance, growth, and migration of this crevasse. Though this study determined that the potential hazard posed by this crevasse is minimal to the existing SPoT route and personnel, the author recommends for future traverses a small $(1 \mathrm{~km})$ course reroute correction, new ground-based radar and global positioning system (GPS) surveys, and continued vigilance and proactive hazard awareness with active real-time surveys.

DISCLAIMER: The contents of this report are not to be used for advertising, publication, or promotional purposes. Citation of trade names does not constitute an official endorsement or approval of the use of such commercial products. All product names and trademarks cited are the property of their respective owners. The findings of this report are not to be construed as an official Department of the Army position unless so designated by other authorized documents. 


\section{Contents}

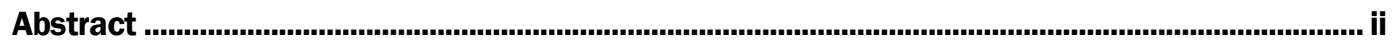

Figures and Tables......................................................................................................................

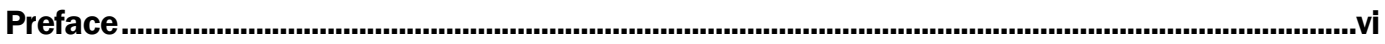

Acronyms and Abbreviations ........................................................................................................

Unit Conversion Factors ..................................................................................................................... vifi

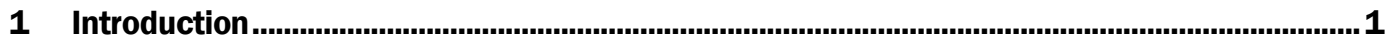

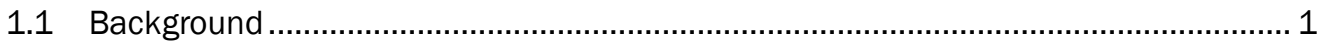

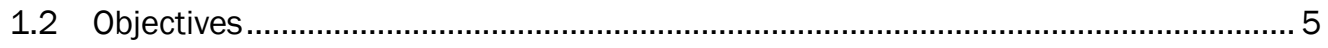

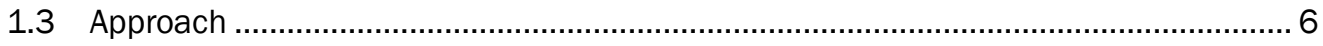

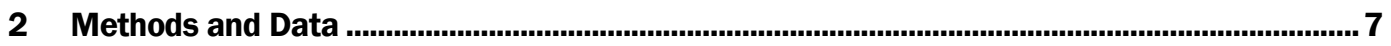

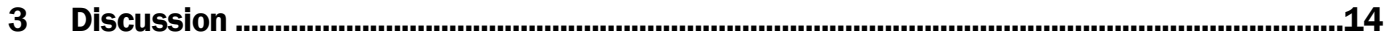

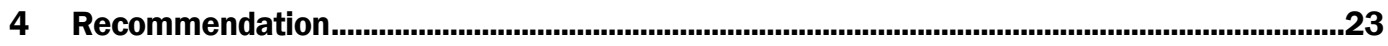

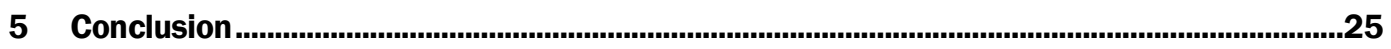

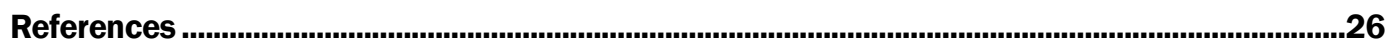

Report Documentation Page 


\section{Figures and Tables}

\section{Figures}

1 Portions of the SPoT caravan shown hauling modified fuel-bladder sleds along the traverse route. Inset shows two rubber-tracked, agricultural tractors used on SPoT (Case Corporation and Caterpillar). (Adapted from Lever and Thur 2014.) ................. 2

2 Map showing the $1600 \mathrm{~km}$ South Pole Traverse (SPoT) route. Red dots indicate global positioning system (GPS) waypoints used by the traverse personnel for navigation

3 Map of Antarctica showing the SPoT route and Leverett Glacier region of interest located along the Transantarctic Mountains in the vicinity of Ice Stream A (see also Fig. 4)

4 A close-up map view of the specific crevassed region of interest on Leverett Glacier illustrated with 5 and $25 \mathrm{~km}$ buffer zones (see also Fig. 3).

5 A close-up map view of the specific crevassed region of interest in this study showing a subset of imagery (blue shaded boxes) available from the Polar Geospatial Center along the SPoT route for the 2015-2016 austral season

6 SPoT route shown with a $5 \mathrm{~km}$ buffer along Leverett Glacier. All digitized crevasses determined from available imagery are identified in dark blue (see also Fig. 7)

7 A close-up view of the SPoT route from Fig. 6, shown with a $5 \mathrm{~km}$ buffer. Crevasses are visible in detail (dark blue) along this $\sim 100 \mathrm{~km}$ section of the traverse route

8 A close-up view of a $25 \mathrm{~km}$ section of the SPoT route near the base of Leverett Glacier. Inset (a) shows an example of a large digitized crevasse field off the route while inset $(b)$ highlights the specific single large crevasse hazard examined in detail in this study (note the proximity to the existing SPoT route)

9 A closer view of the large crevasse hazard shown in Fig. 8. Inset (b) shows a field photograph taken of SPoT personnel during the December 2013 traverse performing a $400 \mathrm{MHz}$ radar ground survey of the snow bridge over the large crevasse. (Photograph by David Weimer.) For spatial reference, a "bump" is identified in both insets $(a)$ and $(b)$. For additional scale, the primary crevasse is approximately $15 \mathrm{~m}$ across near the tractor

10 Compilation of the six satellite images (provided by PGC) showing the primary crevasse (blue dashed line) near the SPoT route (purple line) spanning dates from 24 October 2011 through 1 December 2016 (see also Table 1).

11 Image showing the SPoT route and multiple current grounding-line estimates determined by the MEaSUREs project. The inset shows a close-up view highlighting the proximity of the grounding line to the primary SPOT crevasse $(\sim 15 \mathrm{~km})$

12 RADARSAT-2 (MEaSUREs) ice-velocity map for the Ross Ice Shelf region of Antarctica. The red square indicates the location of the primary Leverett Glacier crevasse. The black line shows the grounding line. (Adapted from Rignot et al. 2011a, 2011b, 2011c.).

13 Map view of the Antarctic shown with the SPoT route and a high-resolution RADARSAT-2 (MEaSUREs) ice-velocity overlay. Inset (a) indicates the location of 
the primary crevasse in a relatively stagnant part of Leverett Glacier. Velocities in scale bar are in $\mathrm{m} \mathrm{yr}^{-1}$

14 Surface elevation map of Antarctica as determined by the ICESat and Bedmap2 projects. The map includes the SPoT route and primary crevasse (insets) for reference.

15 Bed elevation map of Antarctica as determined by the Bedmap2 project. The map includes the SPOT route and primary crevasse (insets) for reference

16 Ice thickness map of Antarctica as determined by the Bedmap2 project. The map includes the SPoT route and primary crevasse (insets) for reference

17 Compiled surface elevation, bed elevation, and ice thickness data along the SPoT route in Antarctica. The inset highlights the primary crevasse at the base of Leverett Glacier (shaded gray and labeled L.G.). Overall ice thickness along the SPoT route is as low as 50 total meters at a distance of roughly $50 \mathrm{~km}$ upstream from the grounding line. Data are shown with approximate errors as published by sources (shaded colors)

18 Map of Antarctica showing all available Automated Weather Stations (installed and maintained by the University of Wisconsin-Madison, Space Science and Engineering Center, Antarctic Meteorological Research Center, NSF grant number ANT-1543305). Inset shows the "Sabrina" station that was used in this study. (Adapted from Lazzara et al. 2012.).

19 Four-month temperature and humidity history from the "Sabrina" AWS roughly $300 \mathrm{~km}$ downstream of Leverett Glacier. Shaded bars indicate days where visual imagery is available of the primary crevasse

20 Prevailing wind from a cardinal direction of $145^{\circ}$ with an average speed of 9.6 $\mathrm{ms}^{-1}$

21 Recommended SPoT reroute shown overlaid on Fig. 8. This reroute involves a single 1-2 km deflection to a new GPS waypoint off the existing route, thus adding a continuous $1 \mathrm{~km}$ safe "buffer space" on all sides

\section{Tables}

1 Leverett Glacier crevasse data derived from the available (2011-16) imagery (asterisk indicates possible snow cover or poor satellite coverage). "Proximity to SPoT" indicates the closest point of the crevasse to the SPoT route (see also

Fig. 10) 


\section{Preface}

This study was conducted for the National Science Foundation (NSF), Office of Polar Programs (OPP), under Engineering for Polar Operations, Logistics, and Research (EPOLAR) EP-ANT-16-26, "Quantifying the Potential Risks and Future Impact of a Large Leverett Glacier Crevasse on the South Pole Traverse (SPoT)." The technical monitor was Margaret Knuth, Program Manager, NSF-OPP, U.S. Antarctic Program.

The work was performed by the Terrestrial and Cryospheric Sciences Branch (CEERD-RRG) of the Research and Engineering Division (CEERD-RR), U.S. Army Engineer Research and Development Center, Cold Regions Research and Engineering Laboratory (ERDC-CRREL). At the time of publication, CDRJ . D. Horne, USN (Ret) was Chief, CEERDRR, and Acting Chief, CEERD-RRG, and J anet Hardy was the program manager for EPOLAR Antarctica. The Deputy Director of ERDC-CRREL was Dr. Lance Hansen, and the Director was Dr. J oseph L. Corriveau.

COL Bryan S. Green was Commander of ERDC, and Dr. David W. Pittman was the Director. 


\section{Acronyms and Abbreviations}

AWS

CRREL

EPOLAR

EPSG

ERDC

GIS

GPS

inSAR

NSF

OPP

PGC

QGIS

SPoT

USAP

WGS 84
Automated Weather Stations

U.S. Army Cold Regions Research and Engineering Laboratory

Engineering for Polar Operations, Logistics, and Research

European Petroleum Survey Group

Engineer Research and Development Center

Geographic Information System

Global Positioning System

Interferometric Synthetic Aperture Radar

National Science Foundation

Office of Polar Programs

Polar Geospatial Center

Quantum Geographic Information System

South Pole Traverse

U.S. Antarctic Program

World Geodetic System 1984 
ERDC/CRREL TR-17-16

viii

Unit Conversion Factors

\begin{tabular}{|l|l|l|}
\hline Multiply & By & To Obtain \\
\hline miles (U.S. statute) & $1,609.347$ & meters \\
\hline pounds (mass) & 0.45359237 & kilograms \\
\hline
\end{tabular}




\section{Introduction}

\subsection{Background}

McMurdo Station, on Ross Island, is the largest facility operated by the United States Antarctic Program (USAP); and it serves as the primary supply hub for the Amundsen-Scott South Pole Station. Historically, all fuel and cargo transported to the South Pole station have been delivered via ski-equipped LC-130 Hercules aircraft operated by the U.S. Air National Guard 109th Division. While effective, these airlift deliveries have come at great financial expense to the U.S. Antarctic Program (USAP) and are susceptible to weather and mechanical delays. In addition, reliance on LC-130 aircraft for station fuel requirements has demanded an extremely hurried pace of operations and can prolong pilot and crew support time provided by the Air National Guard to achieve the necessary 350+flights per austral summer season to South Pole.

In 2000, the USAP proposed assessing the viability of a $1600 \mathrm{~km}$ ( $\sim 1000$ mile) South Pole Traverse (SPoT) as an alternate means and possible lower-cost method to deliver large quantities of fuel and supplies to the Amundsen-Scott South Pole Station. In addition, it was a way to increase the availability of overcommitted on-continent LC-130 aircraft for other critical science project support. After four years of development, the route was successfully traversed for the first time in 2005 as a proof-of-concept, using a combination of several commercial rubber-tracked agricultural tractors (Caterpillar and Case Corporation) that were additionally fitted with optional cold-weather packages. Each tractor hauls specially developed sleds for delivering large bladders of fuel (Figure 1). The project, funded by the National Science Foundation (NSF), resulted in a traverse to South Pole that took approximately 40 days to complete. As of the 201617 Antarctic austral field season, there are now three separate traverses each season along the SPoT route, greatly reducing the number of required LC-130 fuel tanker flights each year. The present SPoT towing tractors are also variously equipped with snow blades, cranes, and other accessories to assist with cargo movement and snow clearing, with a typical tractor weighing between 53,000 and 70,000 lb. Each equipped tractor can pull 8- 10 full fuel bladders (totaling over 160,000-200,000 lb of fuel) and travel at sufficient speeds to cover an average of $40 \mathrm{~km}$ day $^{-1}$. 
Figure 1. Portions of the SPoT caravan shown hauling modified fuel-bladder sleds along the traverse route. Inset shows two rubber-tracked, agricultural tractors used on SPoT (Case Corporation and Caterpillar). (Adapted from Lever and Thur 2014.)

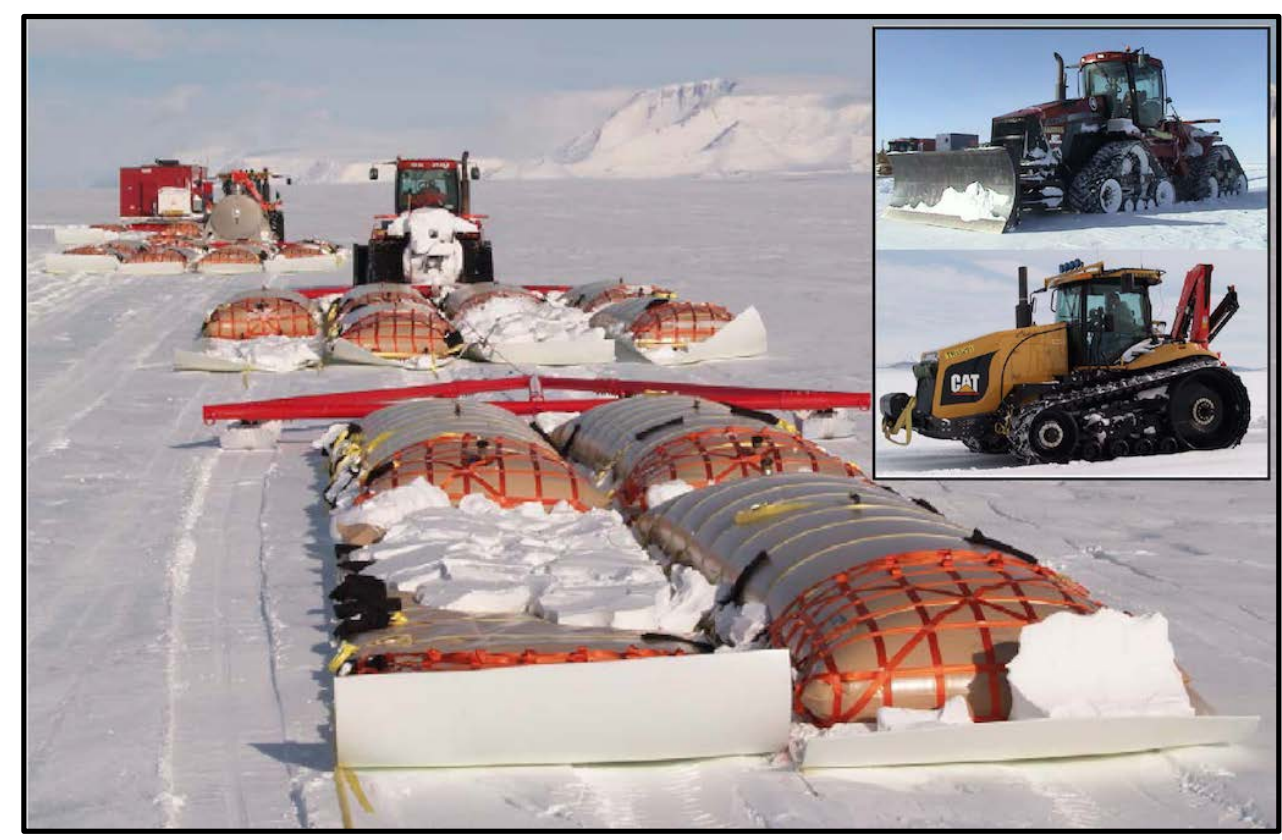

A recent assessment by Lever and Thur (2014) determined that during its first three full operational seasons (2008- 09 to 2010- 11), the SPoT fleet of eight towing tractors delivered an average annual payload of 768,000 lb, most of which was fuel traveling on the high-efficiency bladder sleds. These deliveries offset an average of 30 annual LC- 130 flights (per traverse) to the South Pole that are otherwise needed to deliver the same payload. This offset has significantly lowered the delivery cost of fuel per pound as compared to the LC-130 costs. Lastly, overall average annual $\mathrm{CO}_{2}$ emissions of SPoT is only about $42 \%$ that of a typical season of LC- 130 emissions for comparable fuel delivery, thus greatly reducing the overall environmental impact of USAP within Antarctica and furthering the role of the United States as a steward of the Antarctic Treaty (Lever and Thur 2014; see also Weale and Lever 2008). All of these findings illustrate the efficiency and absolute necessity of maintaining an active annual SPoT campaign for the purposes of fuel and cargo delivery to the AmundsenScott South Pole Station.

The SPoT route leaves the primary U.S. science hub at McMurdo Station and follows a direct-line track over the McMurdo and Ross Ice Shelves in a general southeasterly (grid northwest) direction (Figure 2). For roughly the first $1050 \mathrm{~km}$, the route traverses these ice shelves before making a 
$3000 \mathrm{~m}$ climb up the center of Leverett Glacier starting near the southernmost point of the Ross Ice Shelf. Once up the $100 \mathrm{~km}$ long Leverett Glacier, the SPoT route then moves along a direct-line path high up on the Antarctic Plateau for $450 \mathrm{~km}$ until terminating at the Amundsen-Scott South Pole Station. The McMurdo and Ross Ice Shelves and the Antarctic Plateau are relatively stable; however, crevassing does occur at various points along the SPoT route. While some localized crevasses can be found along the shear zone between the McMurdo and Ross Ice Shelves (near White Island and Minna Bluff), the most copious crevasse hazards are along the steep Leverett Glacier (Figures 3 and 4).

Figure 2. Map showing the $1600 \mathrm{~km}$ South Pole Traverse (SPoT) route. Red dots indicate global positioning system (GPS) waypoints used by the traverse personnel for navigation.

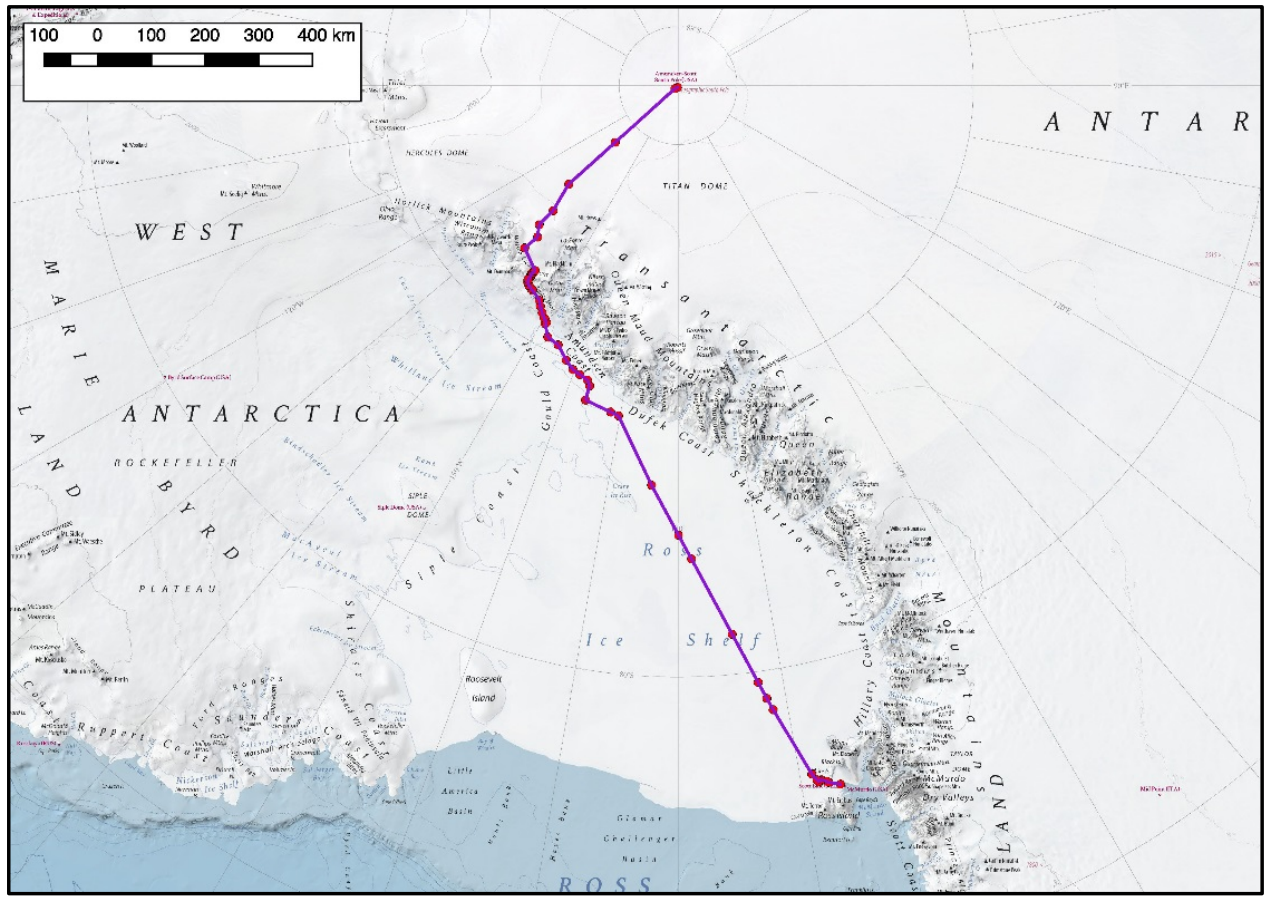


Figure 3. Map of Antarctica showing the SPoT route and Leverett Glacier region of interest located along the Transantarctic Mountains in the vicinity of Ice Stream A (see also Fig. 4).

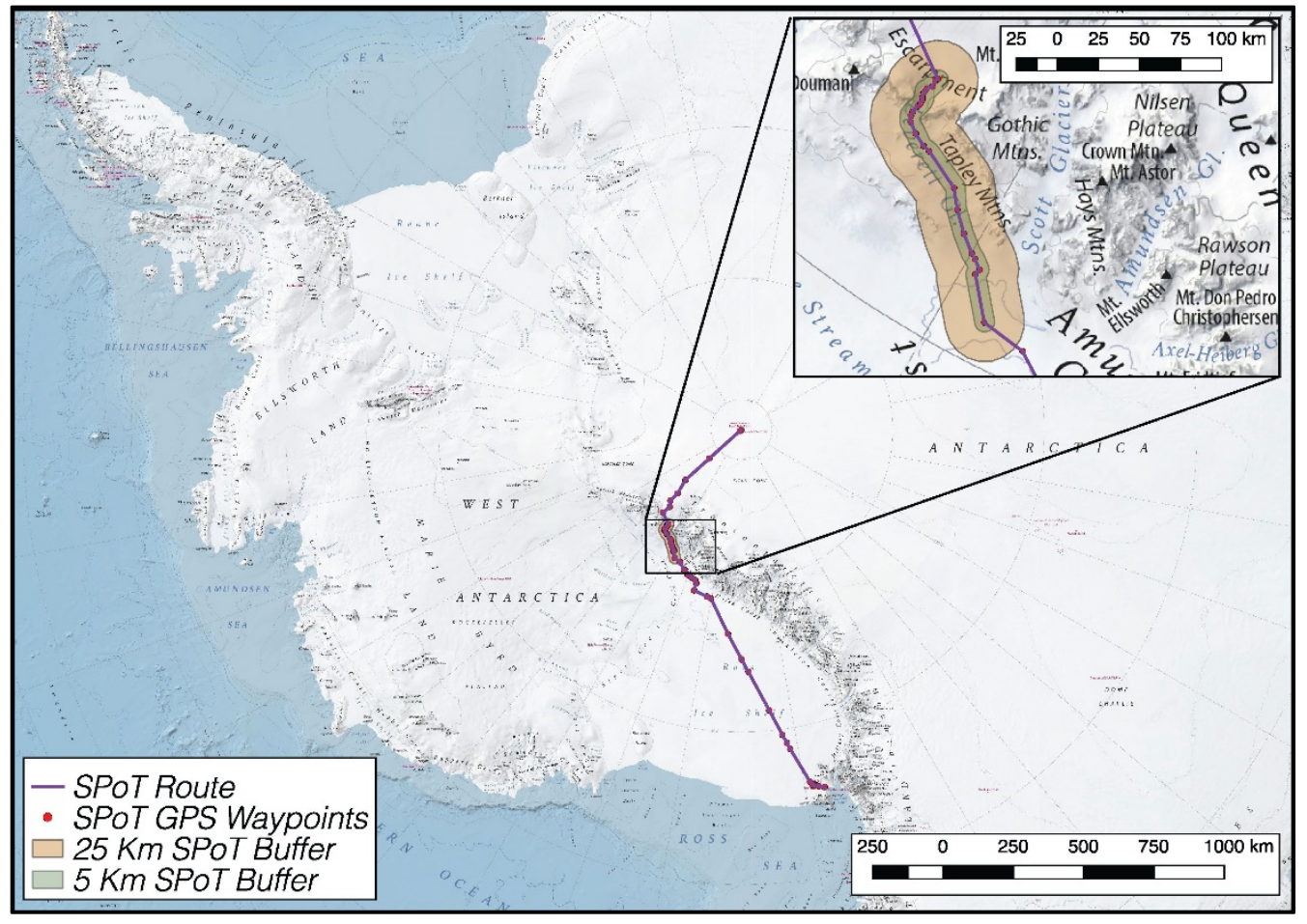

Figure 4. A close-up map view of the specific crevassed region of interest on Leverett Glacier illustrated with 5 and $25 \mathrm{~km}$ buffer zones (see also Fig. 3).

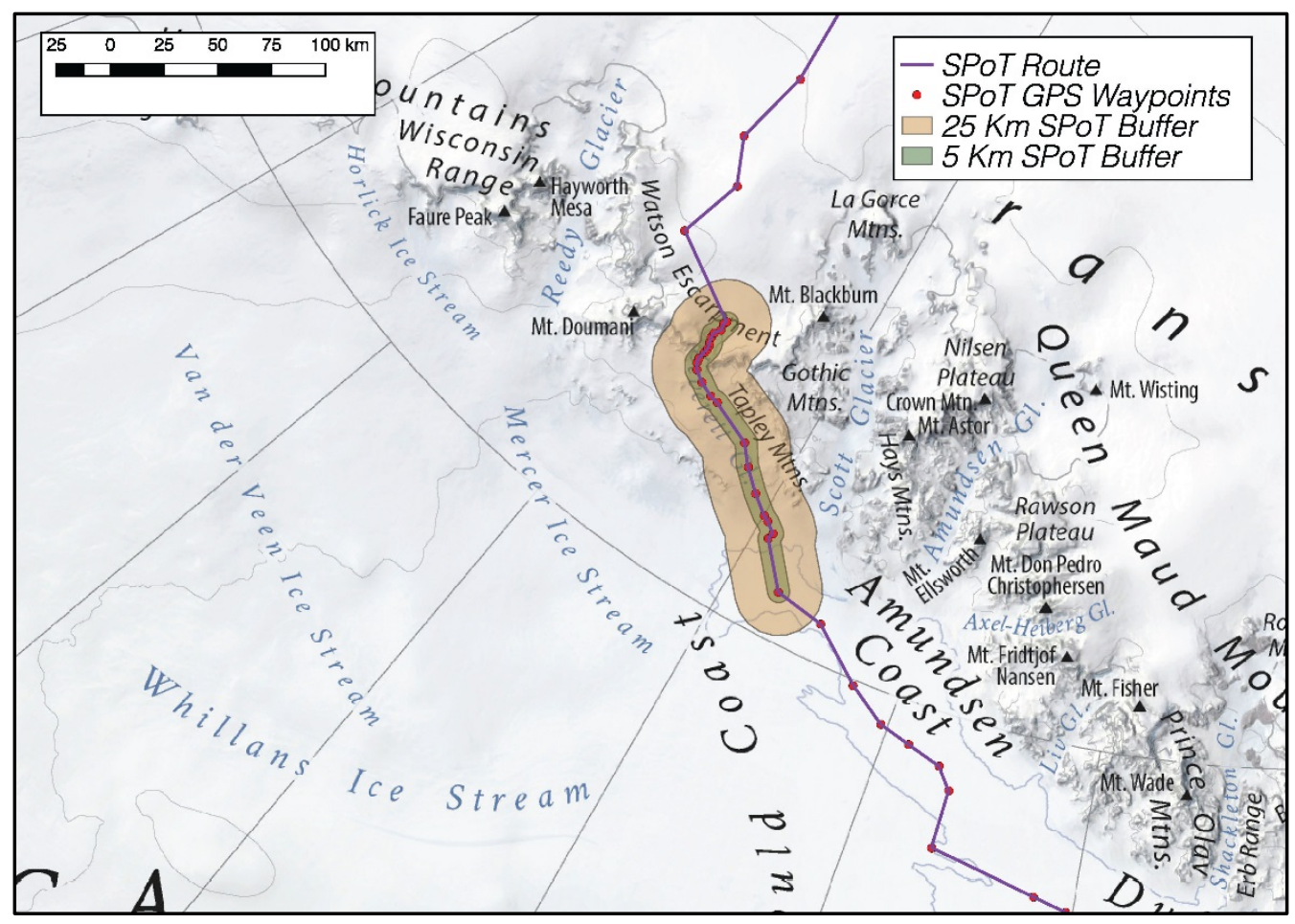


The initial investigations and recommendations for the use of Leverett Glacier as part of the SPoT route were positive and indicated low overall potential risks (Blaisdell et al. 1997; Blaisdell and Bresnahan 2000); however, the behavior and development of crevasses (and crevasse fields) along the route over the past few years could conceivably impede future traverses and the viability of the route in general, resulting in significant delays or reroutes. Furthermore, in December 2013, the inbound SPoT caravan encountered a very large (approximately $15 \mathrm{~m}$ wide and $4 \mathrm{~km}$ long) open crevasse at the very bottom of Leverett Glacier close to the traverse route (only about $200 \mathrm{~m}$ off the direct route). A crevasse of this size and scale and so close to the traverse route could pose a significant safety hazard to the SPoT crew, vehicles, and equipment should it grow or migrate and be encountered unexpectedly. These risks are difficult to quantify as the uncertainties about the migration and possible future growth of the crevasse are not well constrained.

\subsection{Objectives}

Consequently, the National Science Foundation (in conjunction with USAP) determined that these risks warranted more-detailed examination of the spatial and temporal evolution of this specific crevasse. Here, I investigate the historical presence and development of this large crevasse by using a suite of satellite, meteorological, and glaciological data to discern any significant migration or growth over diurnal, seasonal, and yearly time scales and to ascertain any possible correlations.

Ultimately, the aim of this study was to address the following questions regarding this recently discovered crevasse:

- Is the crevasse progressively growing larger, and at what rate?

- Is the crevasse propagating towards the current SPoT route?

- Does the crevasse pose an immediate danger to crew, vehicles, or equipment?

- Is it possible to model the future characteristics and behavior of the crevasse based on available data, including satellite imagery, weather station data, and known ice velocities for Leverett glacier?

- Will there be a potential need to reroute the SPoT, and if so, when? 


\subsection{Approach}

While the fundamentals of glacier sliding, stresses, and velocities have been studied for decades (e.g., Nye 1957; Weertman 1964), many of the specifics related to crevasse growth and propagation are still not well understood. For this study, I compiled the various sets of time series data to determine not only the timing of the crevasse's first appearance but also the possible dynamics related to its growth rate and its spatial extent along the surface. I completed these analyses using a combination of data from the MEaSUREs, RADARSAT, Bedmap2, and WorldView (Polar Geospatial Center) projects (see also Rignot et al. 2011a, 2011b, 2011c; Short and Gray 2004; Fretwell et al. 2013) and meteorological data obtained from nearby Automated Weather Stations (AWS) (Lazzara et al. 2012).

I also made a preliminary effort to model the possible future growth of the crevasse by using recently developed finite-element ice-crevasse-propagation models (Duddu et al. 2013); however, because of model assumptions, the uncertainties surrounding the ice velocities of Leverett Glacier, and the minimal growth and spatial migration of the primary crevasse over the past 5 years, I was not able to determine with a high level of confidence a future crevasse propagation result. Nevertheless, this report includes a full discussion regarding the modeling. 


\section{Methods and Data}

I reviewed cloud-free WorldView-2 satellite (DigitalGlobe) multispectral imagery ( $2 \mathrm{~m}$ resolution) provided by the Polar Geospatial Center (PGC) that was available along the GPS track of the SPoT route. Specifically, I focused on imagery that was available near the potential hazard areas along Leverett Glacier (e.g., Figure 5) that also fell within a $5 \mathrm{~km}$ buffer on either side of the SPoT route. The imagery was radiometrically corrected by DigitalGlobe and orthorectified by PGC. The geolocational error should be minimal here, but some small errors may be possible.

Figure 5. A close-up map view of the specific crevassed region of interest in this study showing a subset of imagery (blue shaded boxes) available from the Polar

Geospatial Center along the SPoT route for the 2015-2016 austral season.

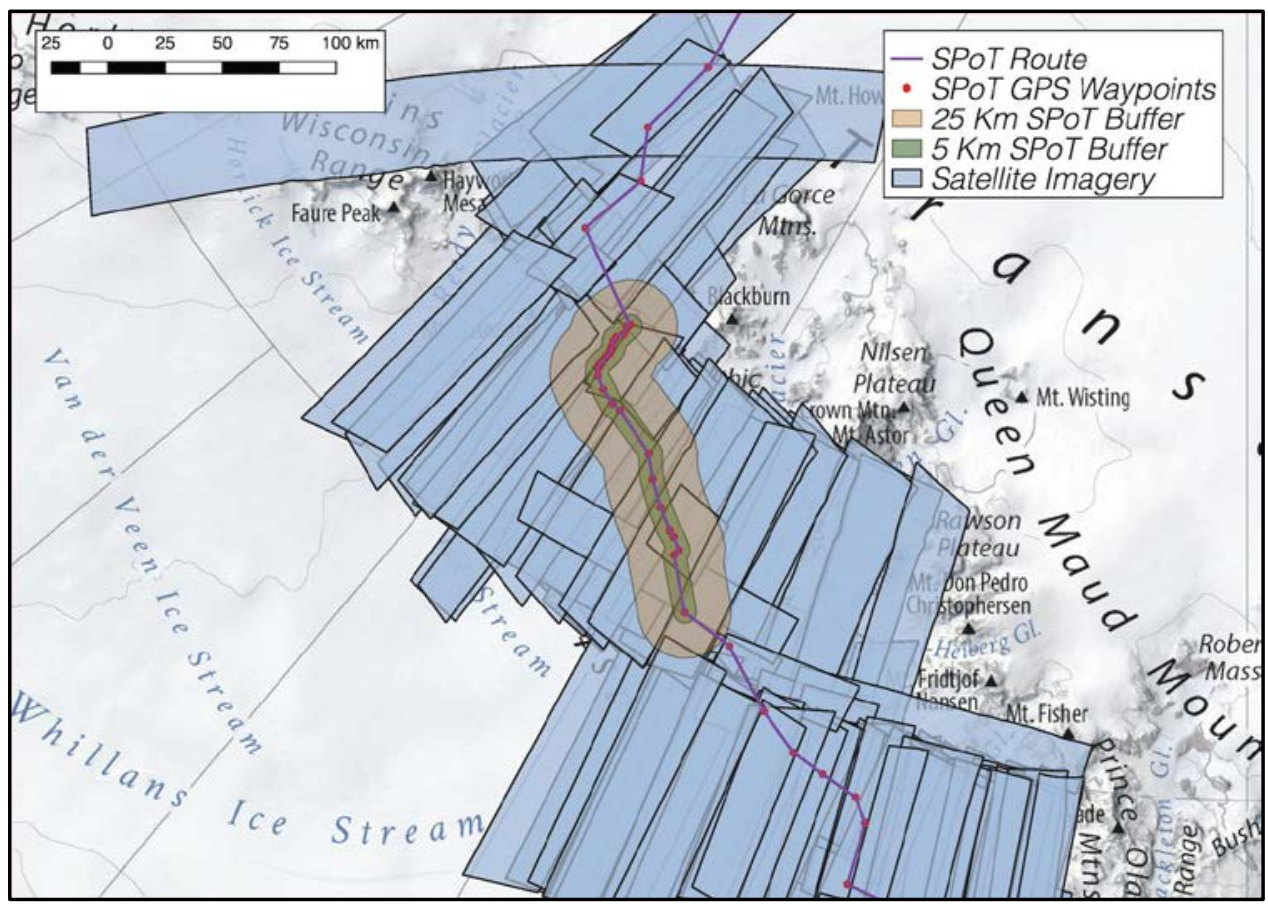

A data set totaling approximately 900 WorldView images collected from 2011 to 2016 during the austral summer months of October through February was available from PGC for download and analysis. These specific months represent the complete temporal window used by the multiple South Pole traverses each year. Images collected in the very early austral summer seasons (October) were often unreliable as they were either less likely to exhibit surface expressions of crevasses due to increased snow cover or had failure with the imagery itself. The majority of the images analyzed here were cloud-free (or nearly cloud-free) and adequate for visual 
analysis with only about 200 ( $22 \%$ ) of the total images being too obscured by clouds or otherwise illegible.

To process the available imagery both temporally and spatially, and as a way to digitize observed crevassing along the route, I used an open-source geographic information system (GIS) software package for the analyses (Quantum GIS, or QGIS). All imagery and applied digital layers within the QGIS software were analyzed using a World Geodetic System 1984 (WGS 84) Polar Stereographic projection template, which is a template that specifies a projection plane or grid tangent to the Earth's surface at latitude $70^{\circ}$ south (see also Pearson 1990; Snyder 1987). This planar grid is designed so that the grid cells at 70 degrees latitude are exactly the nominal grid resolution. Specifically, the WGS 84 or "National Snow and Ice Data Center (NSIDC) - Sea Ice Polar Stereographic North" template (as defined by the European Petroleum Survey Group, or EPSG) was used here.

I first used the QGIS software to digitize a compilation of all identifiable crevasse features by using the available satellite imagery spanning each austral season from 2011- 12 to 2015-16. Within the specific area of interest on the SPoT route along Leverett Glacier, there were numerous visible crevassed areas within the $5 \mathrm{~km}$ route buffer, with a few large notable areas also visible just outside the buffer. I manually digitized over 400 total features by using the available imagery (Figure 6), with obvious patterns emerging in their location, orientation, and grouping near or around apparent zones of high shear along the glacier. As expected, the most abundant crevasse hazards were along the lower section of the $100 \mathrm{~km}$ climb up Leverett Glacier, often oriented parallel (or near parallel) to flow and reducing the safe traverse corridor width to under $3 \mathrm{~km}$ (Figure 7). Many of the features are quite large (over $3 \mathrm{~km}$ long and tens of meters wide), but most are clustered far enough (greater than $5 \mathrm{~km}$ ) away from the traverse route that they do not pose any immediate safety threat to the SPoT crew or vehicles. In many cases, vague linear features suggested possible crevassing (e.g., a buildup of wind-blown snow over an open crevasse or bridge); however, it is also possible that these features were a result of visual artifacts within the imagery. Therefore, I did not process or digitize these images due to their uncertain nature. 
Figure 6. SPoT route shown with a $5 \mathrm{~km}$ buffer along Leverett Glacier. All digitized crevasses determined from available imagery are identified in dark blue (see also Fig. 7).

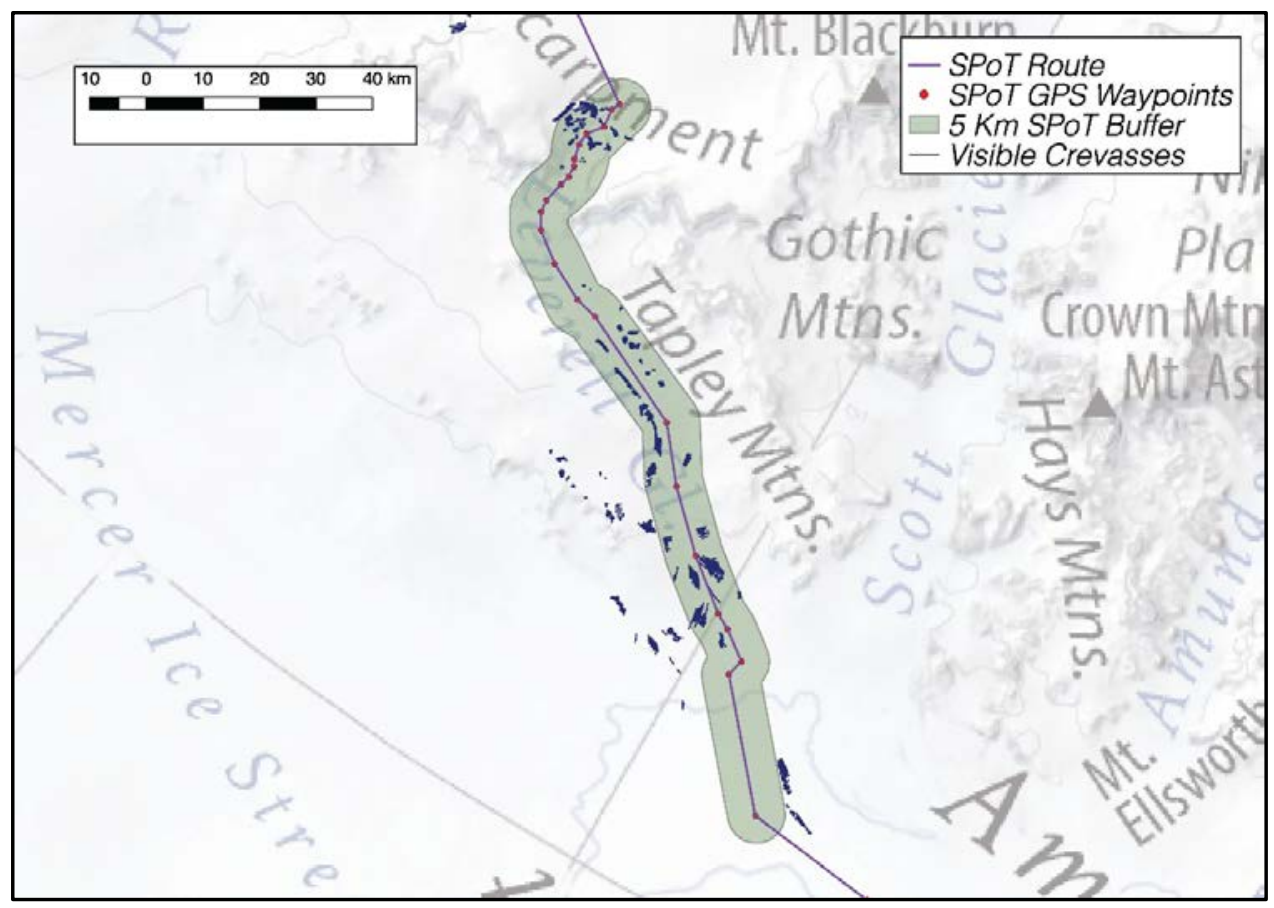

Figure 7. A close-up view of the SPoT route from Fig. 6 , shown with a $5 \mathrm{~km}$ buffer. Crevasses are visible in detail (dark b/ue) along this $\sim 100 \mathrm{~km}$ section of the traverse route.

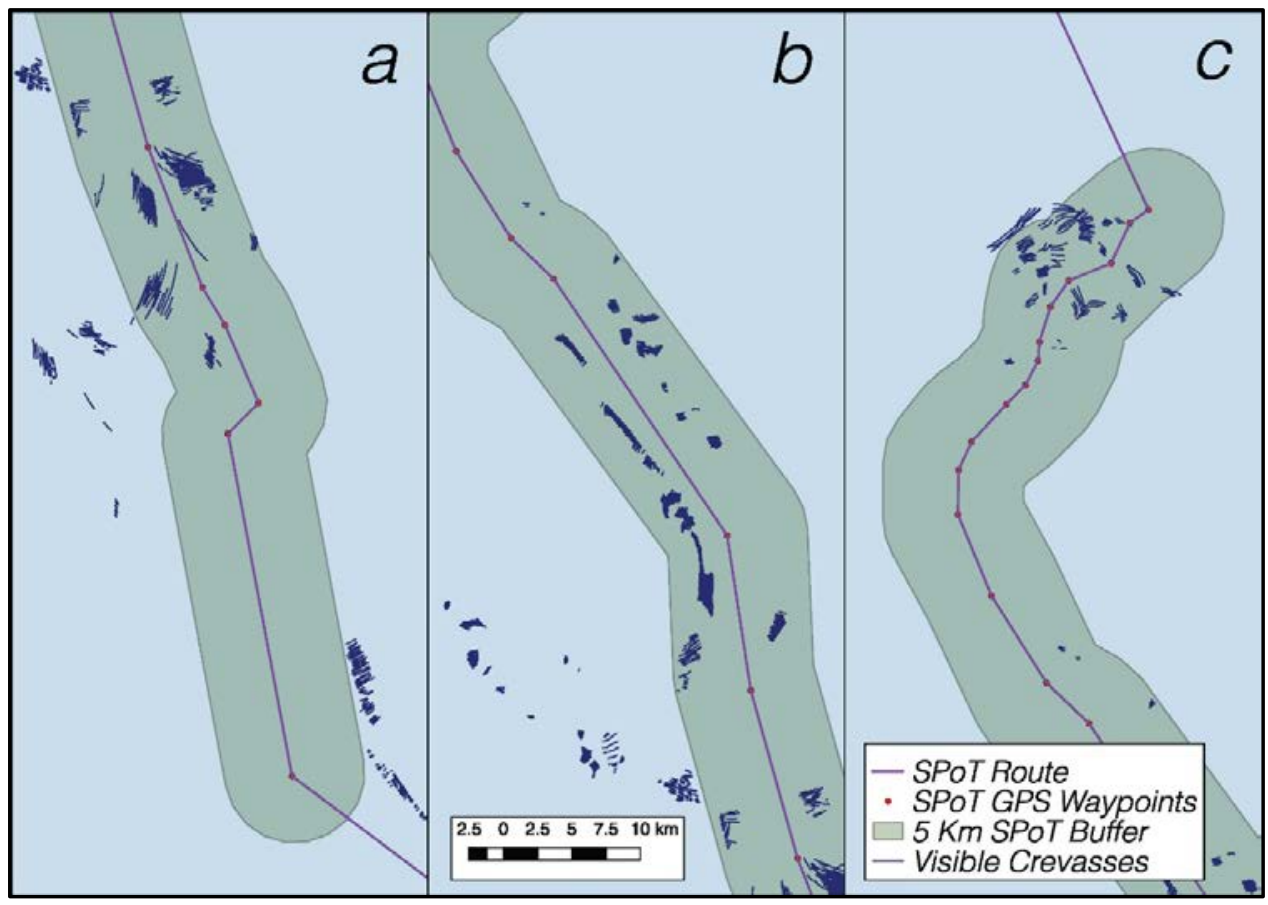

It is also likely that many smaller (but still potentially hazardous) crevasses that would not exhibit any surface expression do exist in areas near the larger, more-exposed crevasses. The large visible crevasses within the 
imagery are of sufficient size (greater than $10 \mathrm{~m}$ wide) that any potential bridges have sagged or failed; however, such smaller crevasses may exist without such surface expressions. Therefore, any lack of visible crevasses in the satellite imagery along Leverett Glacier SPoT route does not preclude their presence. So, regardless of the findings of this study, continued vigilance and proactive hazard awareness is still always essential during every SPoT through the use of active real-time (ground-based) radar surveys.

Truly discerning a more-detailed picture of the extent of active crevassing along Leverett Glacier portion of the SPoT route would require a more robust investigation involving a suite of satellite radar imagery and groundbased surveys. This study, however, focuses instead on the most urgent of the crevasse hazards. Specifically, I examine here the large (approximately $15 \mathrm{~m} \times 4 \mathrm{~km}$ ) open crevasse encountered by the inbound December 2013 SPoT caravan at the bottom of Leverett Glacier less than $200 \mathrm{~m}$ off the primary traverse route (Figures 8 and 9). This crevasse, appears in individual satellite images from 2011 and 2015 and in four separate images from 2016 (imagery from 2012- 14 was either unavailable or obscured by cloud cover). With this set of available coverage for this crevasse (six images total), it was possible not only to analyze long-term trends over the full 5year period but also to observe higher-resolution short-term trends over the 2015- 16 austral season (November 2015- February 2016).

With each of the six usable WorldView images noted above, I measured both the spatial extent along and across the primary crevasse and its closest proximity to the SPoT route by using the native measurement tools within the QGIS software (Table 1 and Figure 10). With the exception of the image from 17 November 2015, which appeared to be partially obscured with fresh snow accumulation drift, all imagery revealed a lengthwise extent for the primary crevasse of approximately $3.9 \mathrm{~km}$. At the widest point, the crevasse measured an average width of about $15 \mathrm{~m}$. Furthermore, over the full 5 years, the crevasse consistently maintained an average "closest proximity" to the SPoT route of approximately $203 \mathrm{~m}$. Because the imagery was orthorectified and geolocated by PGC, I was able to pinpoint the specific GPS coordinates for an identifiable reference point along the crevasse to note its overall absolute movement over the full 5 years. In this case, I used a persistent snow "bump" along the southern side of the crevasse as a visual marker to approximate overall movement (Figure 9). 
Figure 8. A close-up view of a $25 \mathrm{~km}$ section of the SPoT route near the base of Leverett Glacier. Inset (a) shows an example of a large digitized crevasse field off the route while inset $(b)$ highlights the specific single large crevasse hazard examined in detail in this study (note the proximity to the existing SPoT route).

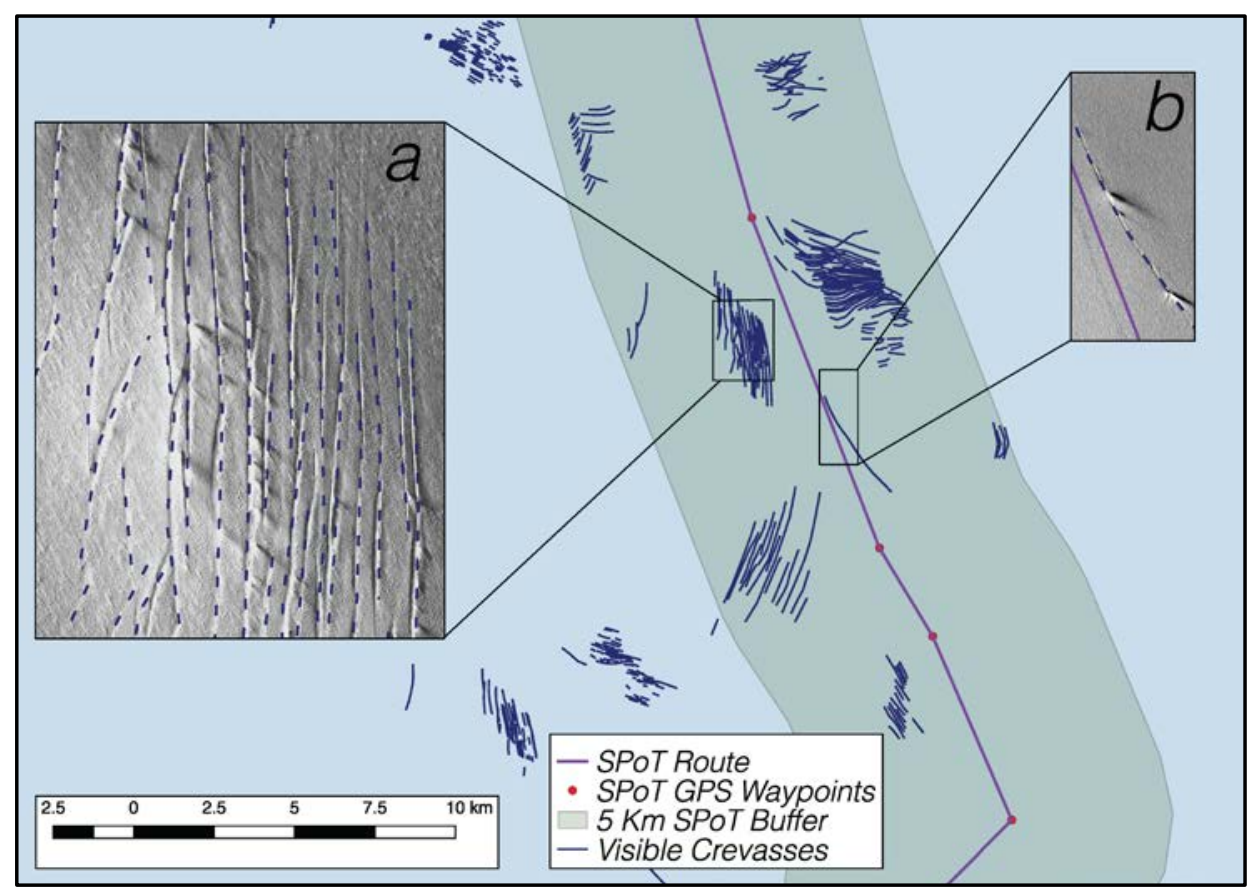

Figure 9. A closer view of the large crevasse hazard shown in Fig. 8. Inset (b) shows a field photograph taken of SPoT personnel during the December 2013 traverse performing a $400 \mathrm{MHz}$ radar ground survey of the snow bridge over the large crevasse. (Photograph by David Weimer.) For spatial reference, a "bump" is identified in both insets $(a)$ and $(b)$. For additional scale, the primary crevasse is approximately $15 \mathrm{~m}$ across near the tractor.

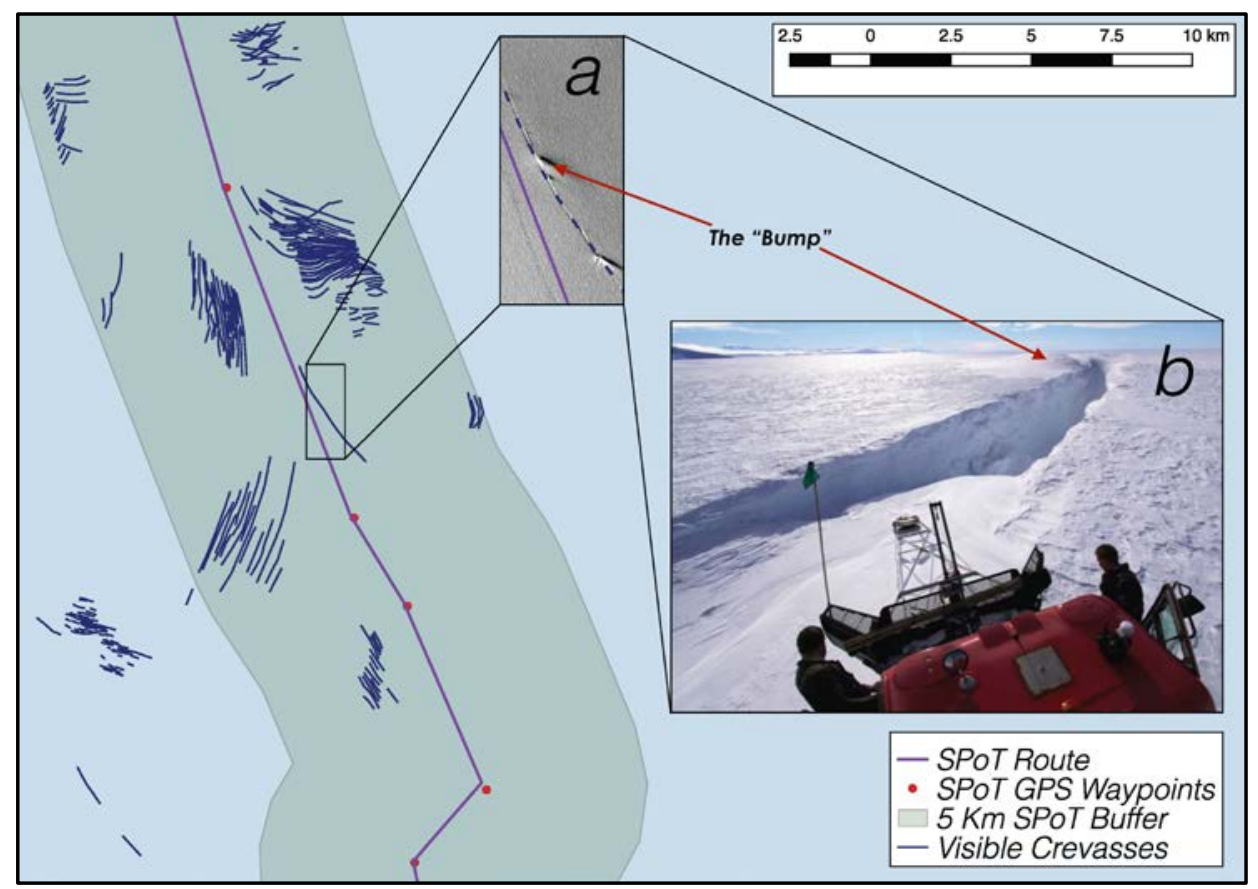


Table 1. Leverett Glacier crevasse data derived from the available (2011-16) imagery (asterisk indicates possible snow cover or poor satellite coverage). "Proximity to SPoT" indicates the closest point of the crevasse to the SPoT route (see also Fig. 10).

\begin{tabular}{|c|c|c|c|}
\hline Date & Total length $(\mathrm{km})$ & Max. width $(\mathrm{m})$ & Proximity to SPoT $(\mathrm{m})$ \\
\hline $11 / 19 / 16$ & 3.7 & 16 & 220 \\
\hline $12 / 01 / 16$ & 3.8 & 15 & 215 \\
\hline $02 / 24 / 16$ & 3.9 & 16 & 190 \\
\hline $01 / 21 / 16$ & 3.9 & 15 & 195 \\
\hline $11 / 17 / 15$ & $2.0^{*}$ & 15 & 200 \\
\hline $10 / 24 / 11$ & 3.4 & 15 & 200 \\
\hline
\end{tabular}

Figure 10. Compilation of the six satellite images (provided by PGC) showing the primary crevasse (blue dashed line) near the SPoT route (purple line) spanning dates from 24 October 2011 through 1 December 2016 (see also Table 1).
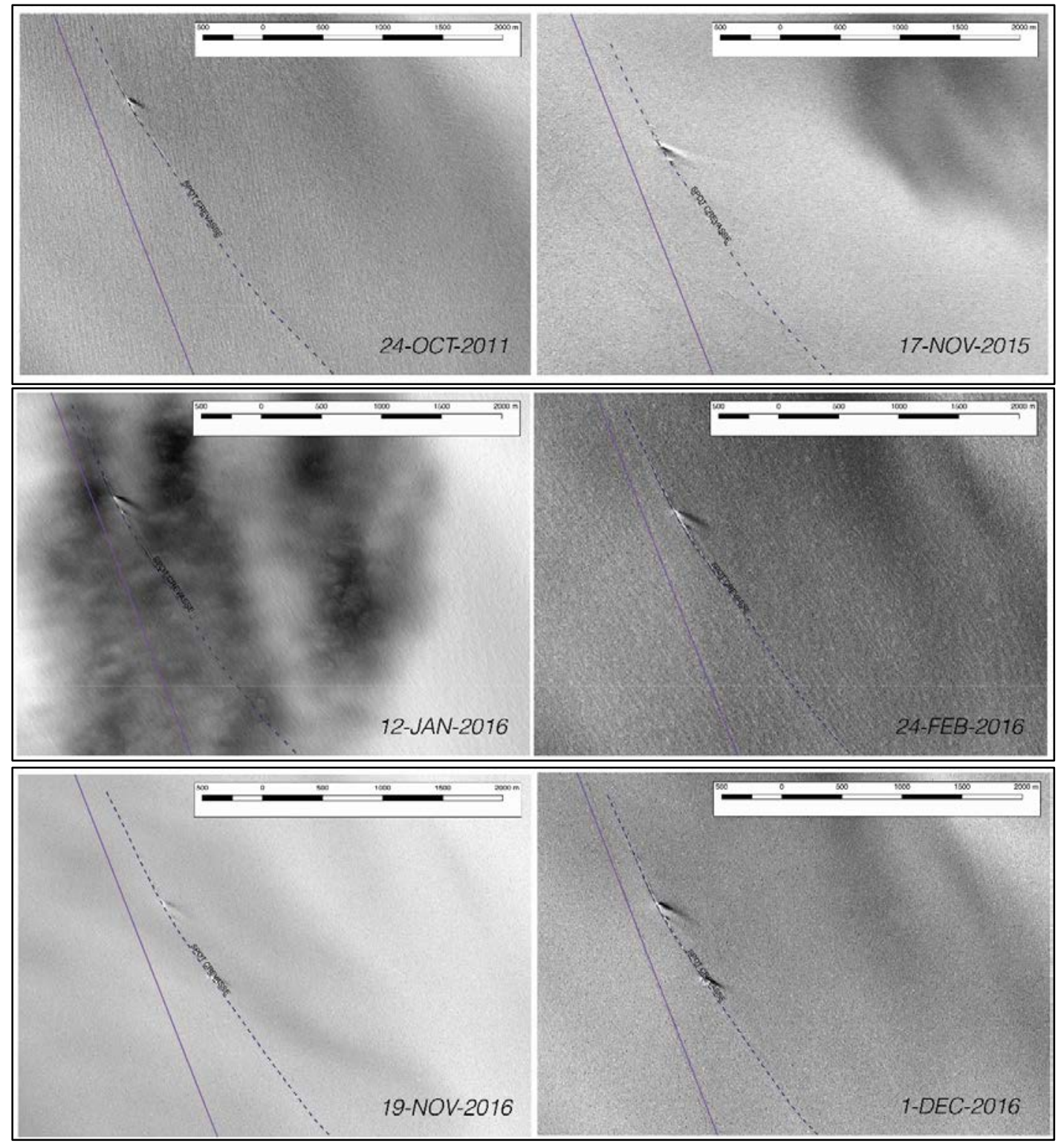
The behavior of the crevasse was notably static, and it appeared consistently open across and through multiple austral seasons; the crevasse did not expand or migrate significantly over the course of any single full summer seasonal cycle. Over the entire 5 years, the crevasse migrated only about 241 total absolute meters down glacier. This minimal movement equates to an average of only about $13 \mathrm{~cm} \mathrm{day}^{-1}$, or roughly an order of magnitude lower than the $1+\mathrm{m}$ day $^{-1}$ that is expected for a fast flowing outlet glacier like Leverett. This suggests that the crevasse is relatively stable and stationary and may be a result of a response by the ice to a bedrock feature rather than to a specific influence of increased surface shear. On further investigation of available ice-velocity data for Leverett Glacier (see Rignot et al. 2011a, 2011b, 2011c), it appears that this portion of the glacier may actually be quite stagnant, which is also consistent with the observed behavior of this primary crevasse. A basal asperity (i.e., "sticky spot") may be affecting the flow dynamics of this portion of the glacier (e.g., Anandakrishnan and Alley 1994, 1997). To truly answer this question, a groundbased GPS velocity survey would be necessary to measure year-to-year real-time flow velocities. The next section presents a more-detailed discussion regarding the possibility of a basal asperity, or "sticky spot," affecting Leverett Glacier near this primary crevasse and the proximity of this portion of the glacier to the Antarctic primary grounding line. 


\section{Discussion}

In addition to the available WorldView visual-band satellite imagery, I also examined various supplementary data sets to better constrain the glaciological and meteorological setting near the primary crevasse on Leverett Glacier. Using interferometric synthetic aperture radar (inSAR) data from the MEaSUREs project (Rignot et al. 2011c), I determined that the area near the primary crevasse on Leverett Glacier is approximately $15 \mathrm{~km}$ upstream of the calculated grounding line (Figure 11). This result indicates that the primary crevasse is on grounded ice and therefore not under the direct influence of water from underneath the Ross Ice Shelf. It is possible, however, that because of the relative proximity of the primary crevasse to the grounding line, there is a nontrivial tidal influence on the grounded ice near the crevasse. In a recent study aimed at better constraining the influence of stress changes over floating ice shelves on nearby grounded ice streams, Minchew et al. (2017) determined that ocean-tide-induced variability in vertical ice-shelf position and horizontal ice-stream flow is a result of periodic grounding of the ice shelf. Ultimately, they determined that tide-induced variability can lead to periodic measurable stagnation and instability of ice-flow velocities as far as $85 \mathrm{~km}$ upstream of the grounding line, which would include our primary crevasse region of interest.

Figure 11. Image showing the SPoT route and multiple current grounding-line estimates determined by the MEaSUREs project. The inset shows a close-up view highlighting the proximity of the grounding line to the primary SPoT crevasse $(\sim 15 \mathrm{~km})$.

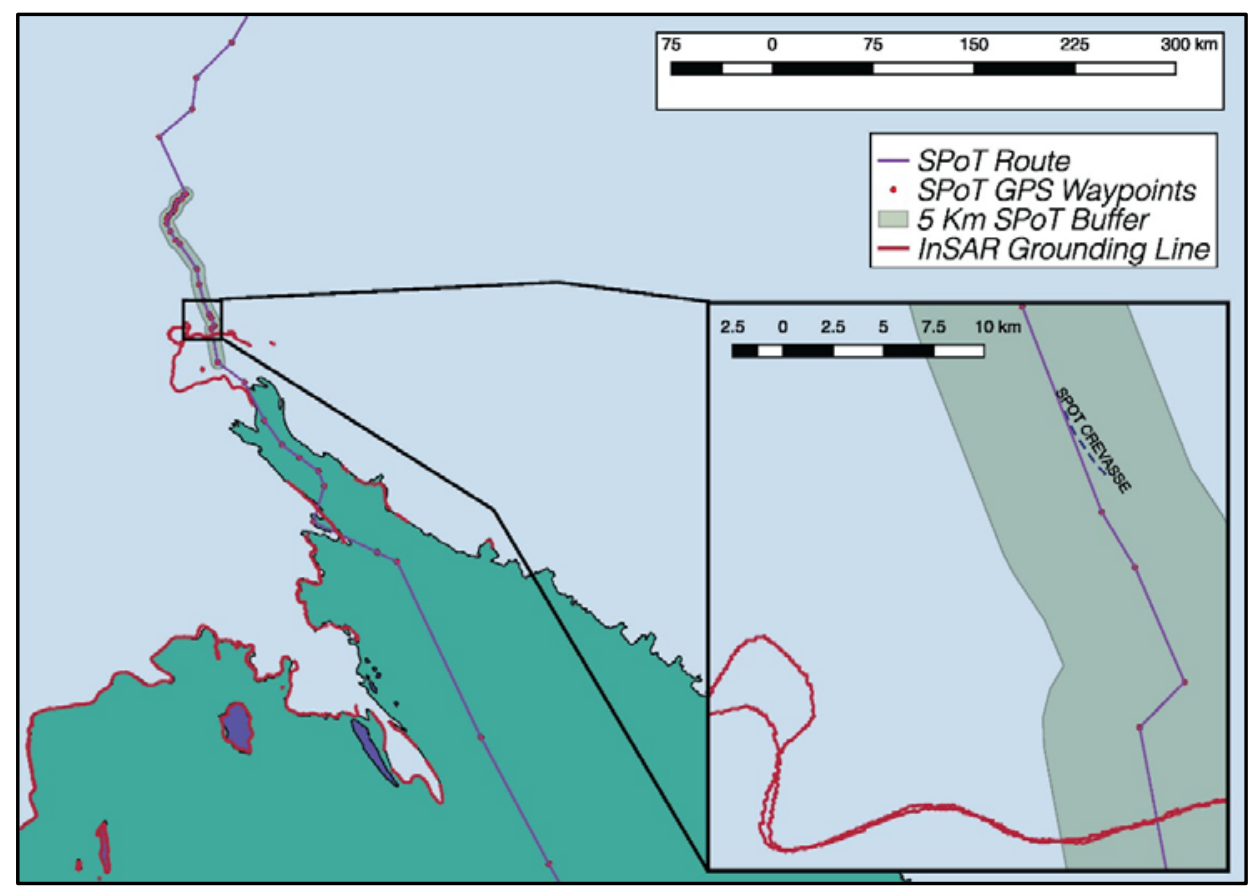


As part of the MEaSUREs data, I also analyzed remotely sensed ice-velocity data collected by the RADARSAT-2 satellite (Rignot et al. 2011a, 2011b, 2011c; Short and Gray 2004). A preliminary map of ice-velocity data does appear to show relatively slow (less than $100 \mathrm{~m} \mathrm{yr}^{-1}$ ) average flow velocities in the area surrounding the primary crevasse on Leverett Glacier (Figure 12). Furthermore, a more-detailed examination of the area in the immediate vicinity of the primary crevasse reveals no obvious isolines or color contours (Figure 13). This discovery further corroborates the observation that the lower portion of Leverett Glacier is moving at roughly an order of magnitude slower than other nearby glaciers, such as Scott Glacier and Amundsen Glacier. These data also indicate that as close as $10 \mathrm{~km}$ downstream of the primary crevasse at the confluence of Leverett Glacier with Scott Glacier, velocities increase to greater than $300 \mathrm{~m} \mathrm{yr}^{-1}$. This sharp transition could therefore be contributing to the increased crevassing upstream of the confluence due to larger associated stresses (see Figure 6 and Figure 7a).

Figure 12. RADARSAT-2 (MEaSUREs) ice-velocity map for the Ross Ice Shelf region of Antarctica. The red square indicates the location of the primary Leverett Glacier crevasse. The black line shows the grounding line. (Adapted from Rignot et al. 2011a, 2011b, 2011c.)

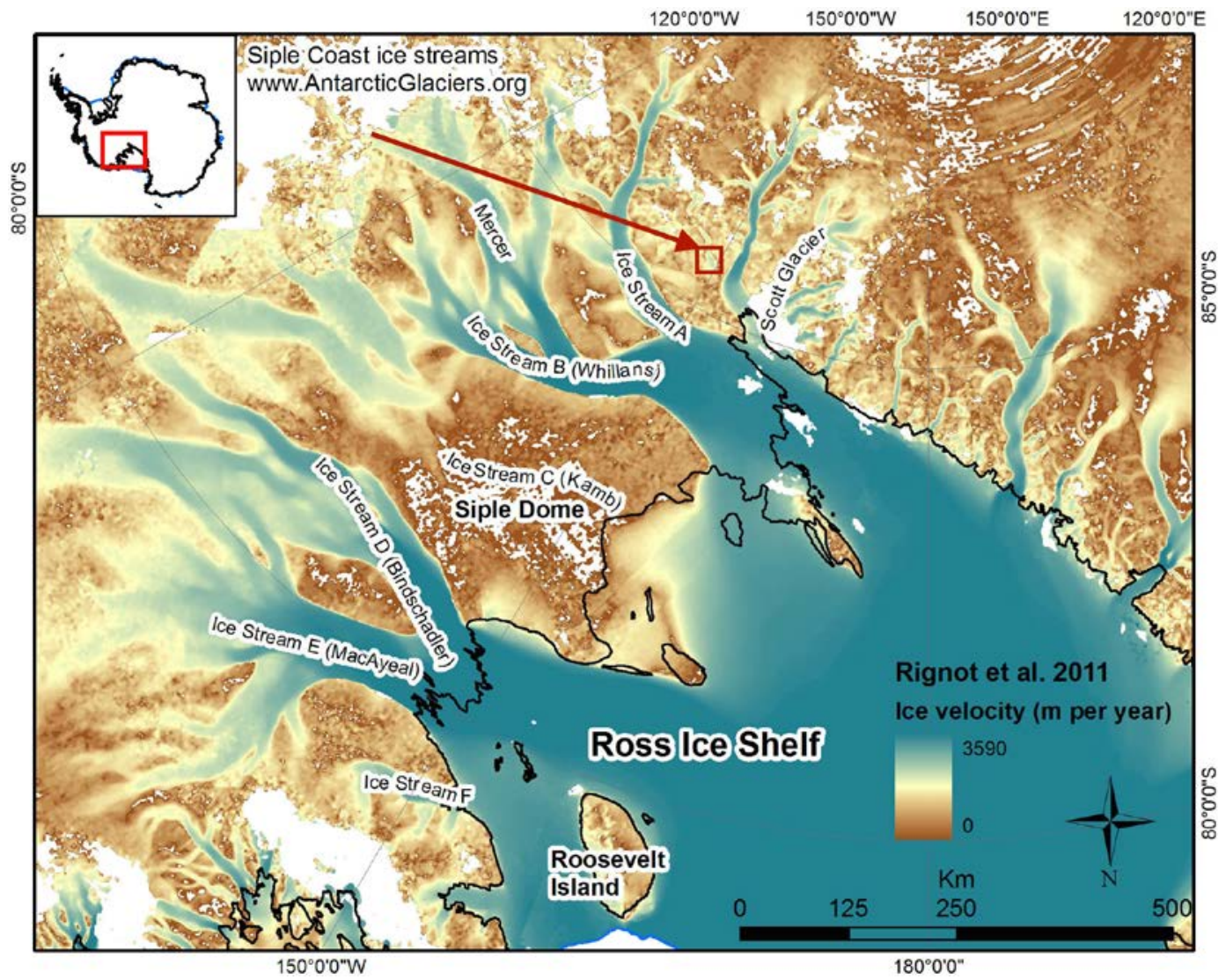


Figure 13. Map view of the Antarctic shown with the SPoT route and a high-resolution RADARSAT-2 (MEaSUREs) ice-velocity overlay. Inset (a) indicates the location of the primary crevasse in a relatively stagnant part of Leverett Glacier. Velocities in scale bar are in $\mathrm{m} \mathrm{yr}^{-1}$.

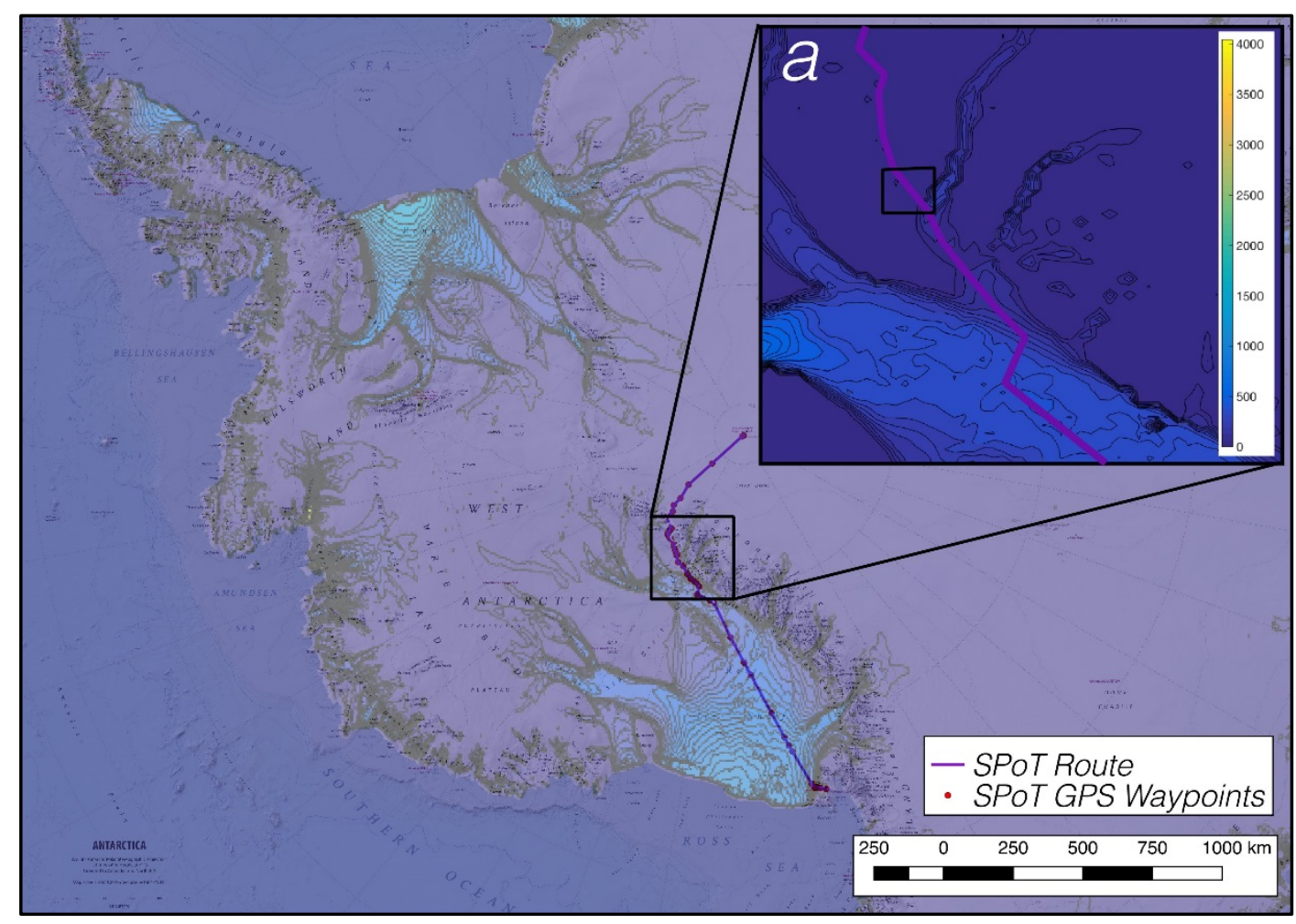

I also examined a suite of gridded digital elevation data products that describe surface elevation (i.e., satellite radar altimetry), ice thickness, and the sea floor and subglacial bed elevation in the Antarctic south of $60^{\circ} \mathrm{S}$ (Figures 14-16). Specifically, I used data available from both the ICESat and Bedmap2 projects (Fretwell et al. 2013; Bamber et al. 2009; Griggs et al. 2009) with the objective to better constrain ice thickness along the SPoT route. The analysis revealed significant variations in bed elevation and ice thicknesses along the portion of the route up Leverett Glacier (Figure 17). Remarkably, total ice thicknesses on Leverett Glacier along the SPoT route are as high as $1000 \mathrm{~m}$ near the grounding line but as low as 50 meters $( \pm 20 \mathrm{~m})$ at a distance of about $50 \mathrm{~km}$ upstream from the grounding line. At the location of the primary crevasse encountered by the SPoT personnel, the total ice thickness is between 900 and $1000 \mathrm{~m}$, with the crevasse beginning at a high surface elevation of $385 \mathrm{~m}$ above sea level and terminating approximately $4 \mathrm{~km}$ downstream at a surface elevation of 315 $\mathrm{m}$. This net decrease in surface elevation of $70 \mathrm{~m}$ equates to an approximate $1^{\circ}$ downslope gradient. 
Figure 14. Surface elevation map of Antarctica as determined by the ICESat and Bedmap2 projects. The map includes the SPoT route and primary crevasse (insets) for reference.

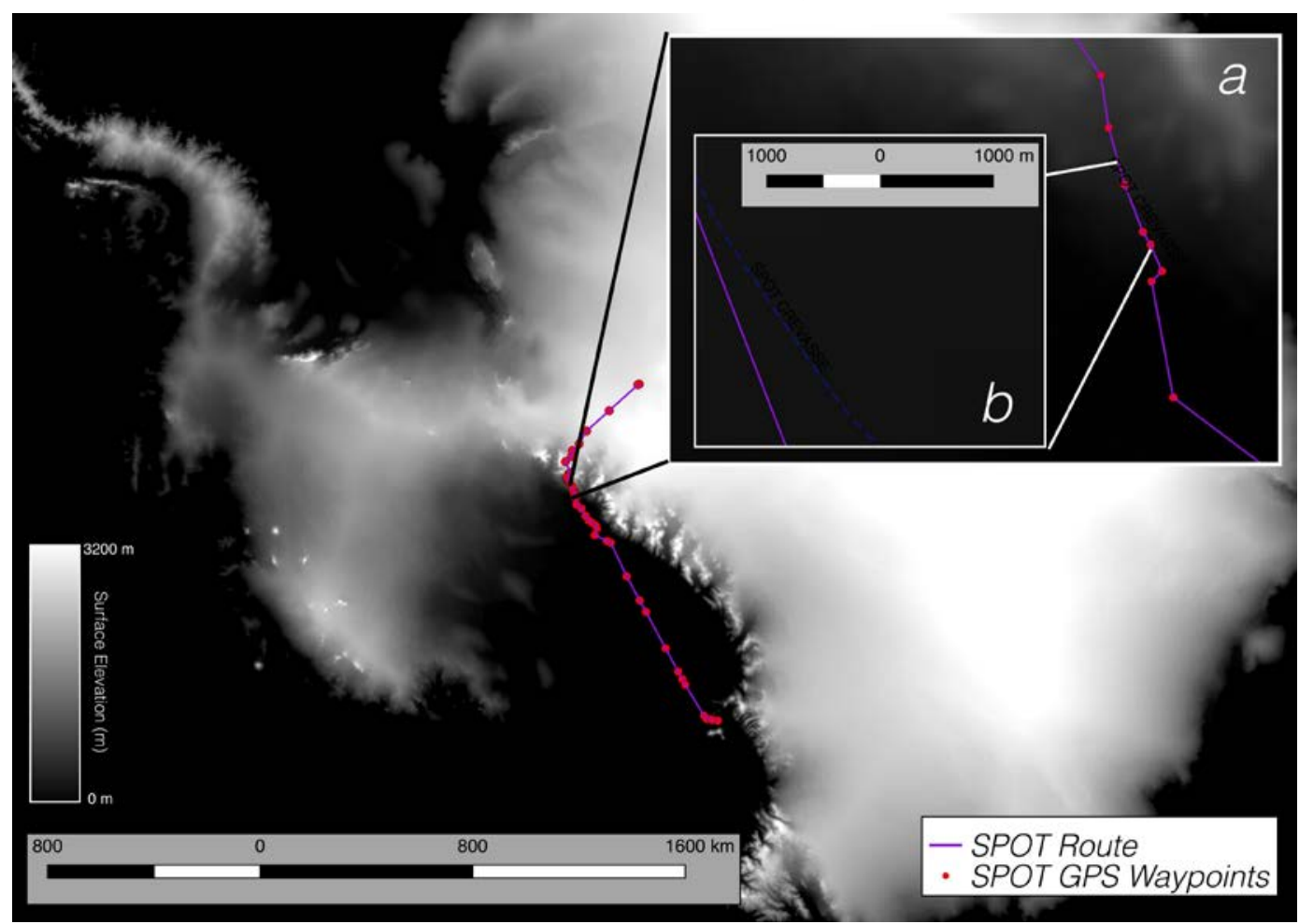

Figure 15. Bed elevation map of Antarctica as determined by the Bedmap2 project. The map includes the SPOT route and primary crevasse (insets) for reference.

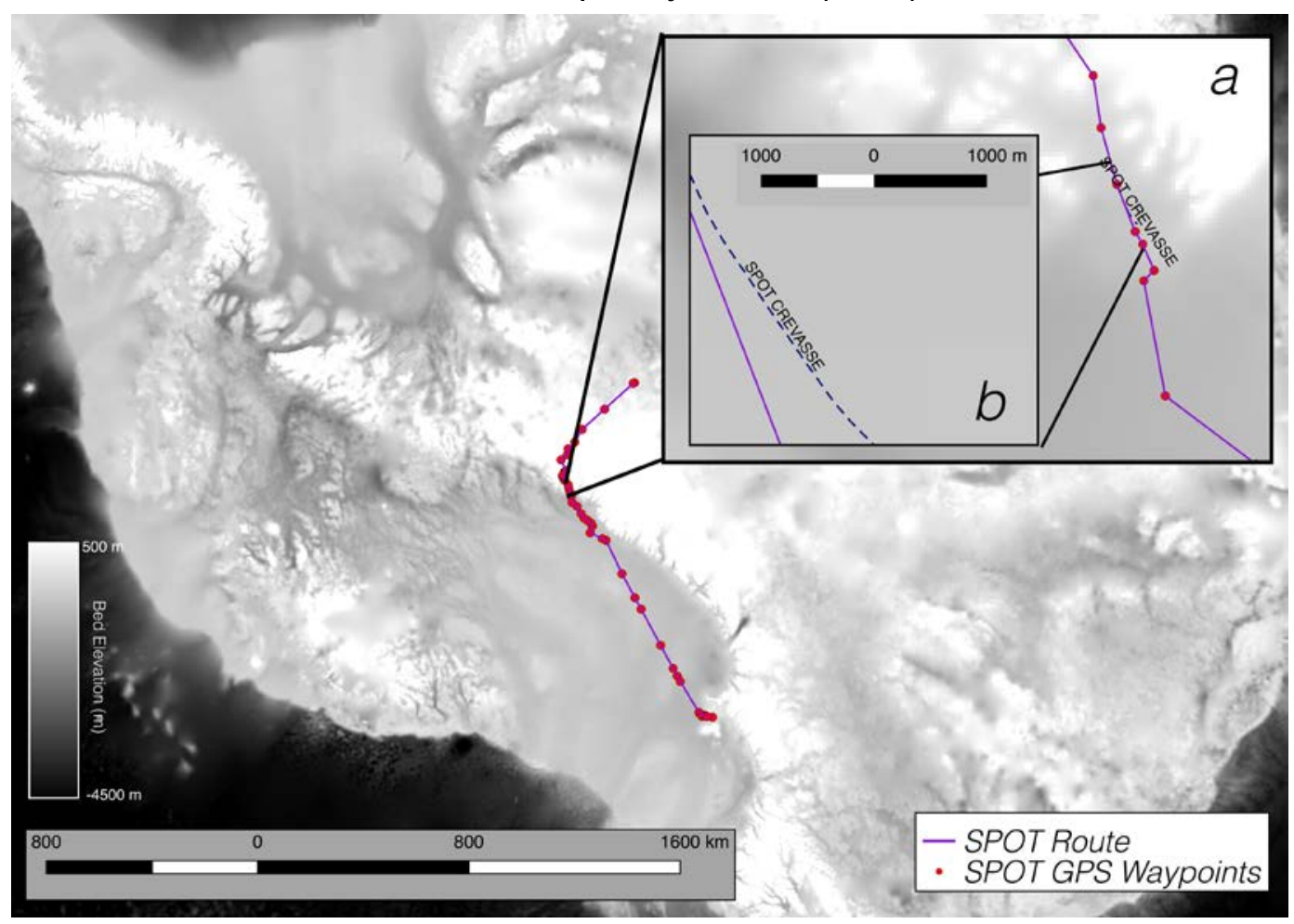


Figure 16. Ice thickness map of Antarctica as determined by the Bedmap2 project. The map includes the SPOT route and primary crevasse (insets) for reference.

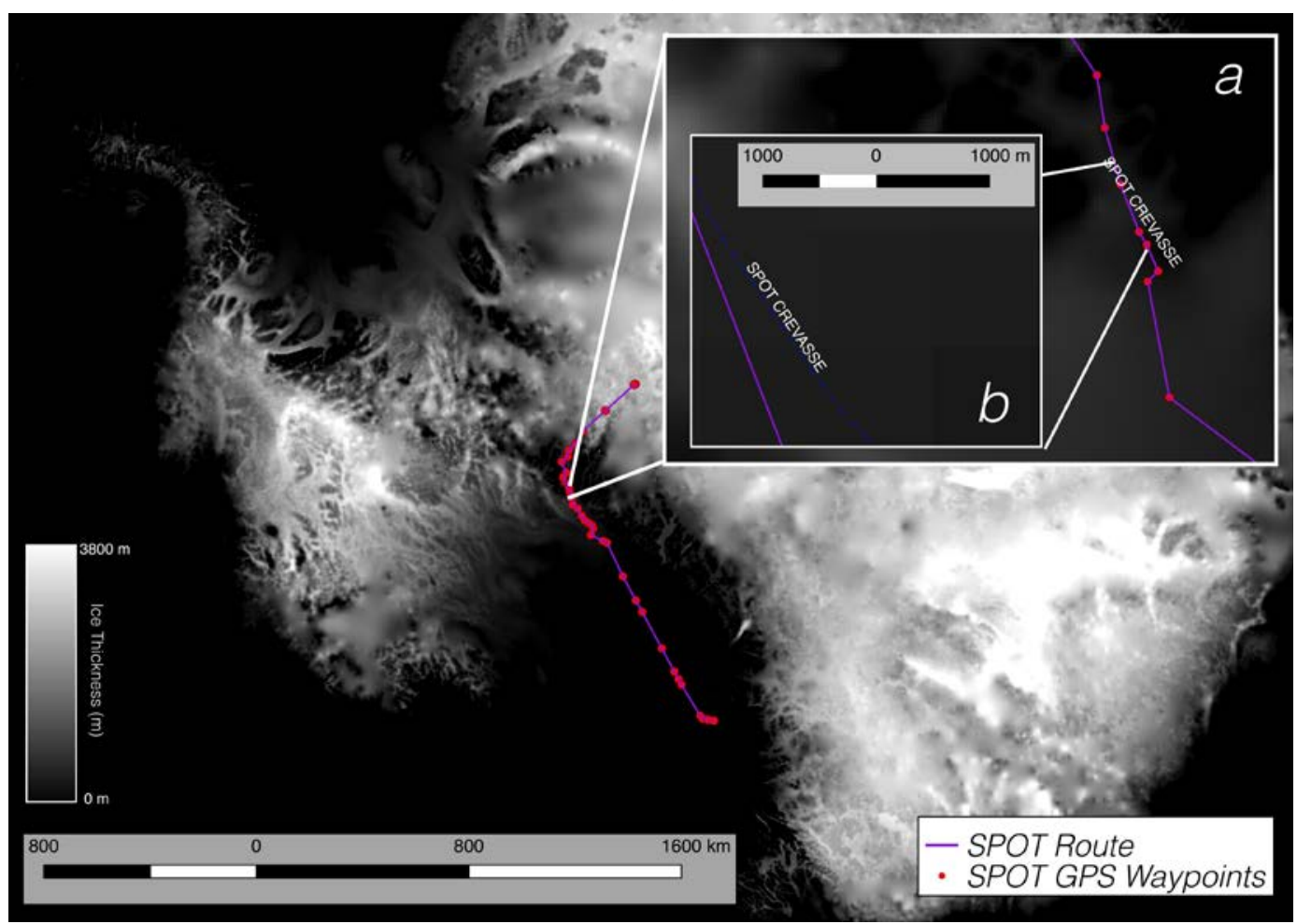

Figure 17. Compiled surface elevation, bed elevation, and ice thickness data along the SPoT route in Antarctica. The inset highlights the primary crevasse at the base of Leverett Glacier (shaded gray and labeled L.G.). Overall ice thickness along the SPoT route is as low as 50 total meters at a distance of roughly $50 \mathrm{~km}$ upstream from the grounding line. Data are shown with approximate errors as published by sources (shaded colors).

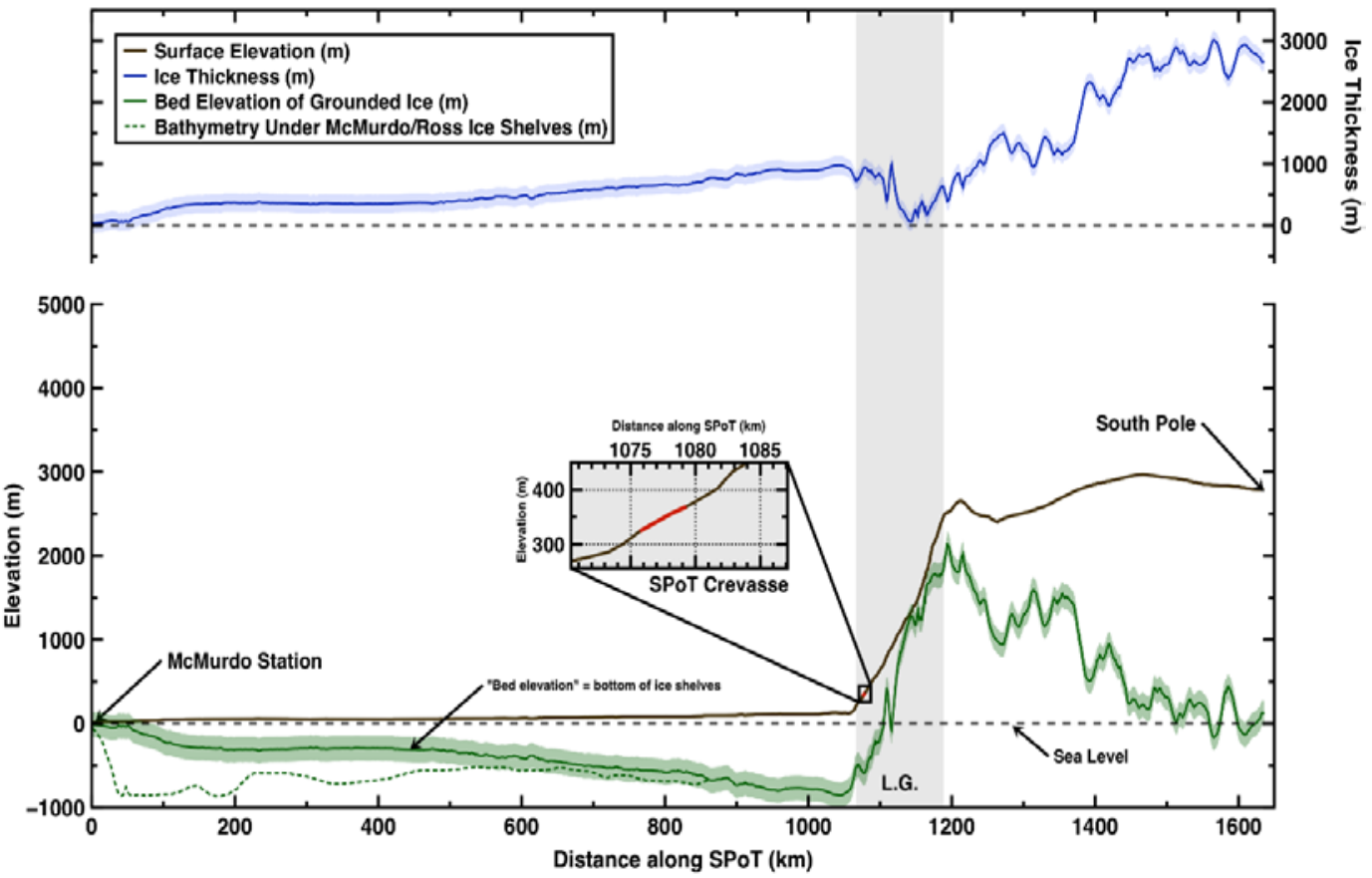


While difficult to speculate, such noteworthy variability in the ice thickness up and down Leverett Glacier, combined with the aforementioned changes in ice velocity near the confluence with Scott Glacier, would likely result in notably dynamic ice flow with unpredictable behavior and crevassing, despite the apparent year-to-year stability of several of the larger crevasses. As previously stated, a more-detailed investigation involving a suite of satellite radar imagery and dedicated ground-based surveys would be required to truly quantify this behavior.

I also completed a cursory meteorological investigation in the vicinity of Leverett Glacier by using publicly available AWS data through the University of Wisconsin AWS program (Lazzara et al. 2012). Specifically, I analyzed the 2015- 16 austral seasonal cycle to pinpoint any regional trends in meteorological conditions related to the observed Leverett Glacier crevassing across a full seasonal SPoT campaign (November- February). I was also looking for any evidence of potential melt episodes that could contribute water to the basal hydrological network near Leverett Glacier. There is no AWS on Leverett Glacier or near the primary crevasse, so I used data ( $3 \mathrm{hr}$ interval) from the "Sabrina" station located on the Ross Ice Shelf approximately $300 \mathrm{~km}$ downstream of the crevassed area (see Figure 18).

Over the course of the approximate 4-month period, trends were consistent with expectations for the area with no obvious aberrations or anomalies. Average measured temperature and humidity were $-9^{\circ} \mathrm{C}$ and $70.6 \%$, respectively, with only two short episodes of above-freezing temperatures (both of which stayed below $3^{\circ} \mathrm{C}$ ) (Figure 19). Assuming a dry adiabatic lapse rate of $1^{\circ} \mathrm{C} / 100 \mathrm{~m}$ up Leverett Glacier and given the elevation of the primary crevasse as being at least $300 \mathrm{~m}$ above sea level, there were likely no days that experienced melt-favorable conditions near the primary crevasse. There were no significant correlations between the meteorological conditions and dates of available imagery of the primary crevasse. Prevailing wind direction was from a cardinal direction of $145^{\circ}$ with an average speed of $9.6 \mathrm{~m} \mathrm{~s}^{-1}$, which is oriented along, and consistent with, a dominant katabatic wind blowing down Leverett Glacier from the Polar Plateau (Figure 20). Thus, based on these data and observations, it is unlikely that the regional meteorological setting had any discernable active influence on the behavior of the primary crevasse on Leverett Glacier. 
Figure 18. Map of Antarctica showing all available Automated Weather Stations (installed and maintained by the University of Wisconsin-Madison, Space Science and Engineering Center, Antarctic Meteorological Research Center, NSF grant number ANT-1543305). Inset shows the "Sabrina" station that was used in this study. (Adapted from Lazzara et al. 2012.)

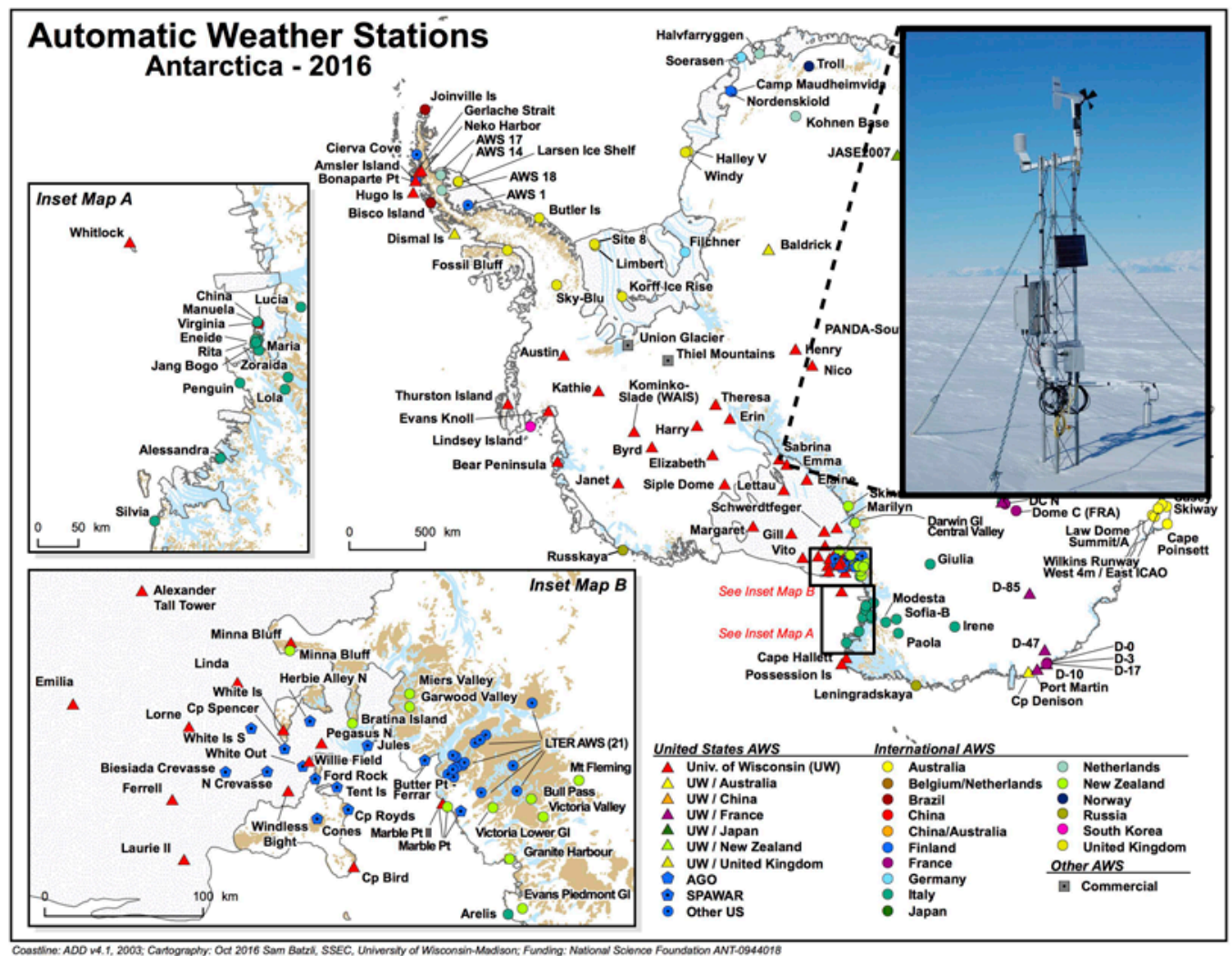

Figure 19. Four-month temperature and humidity history from the "Sabrina" AWS roughly $300 \mathrm{~km}$ downstream of Leverett Glacier. Shaded bars indicate days where visual imagery is available of the primary crevasse.

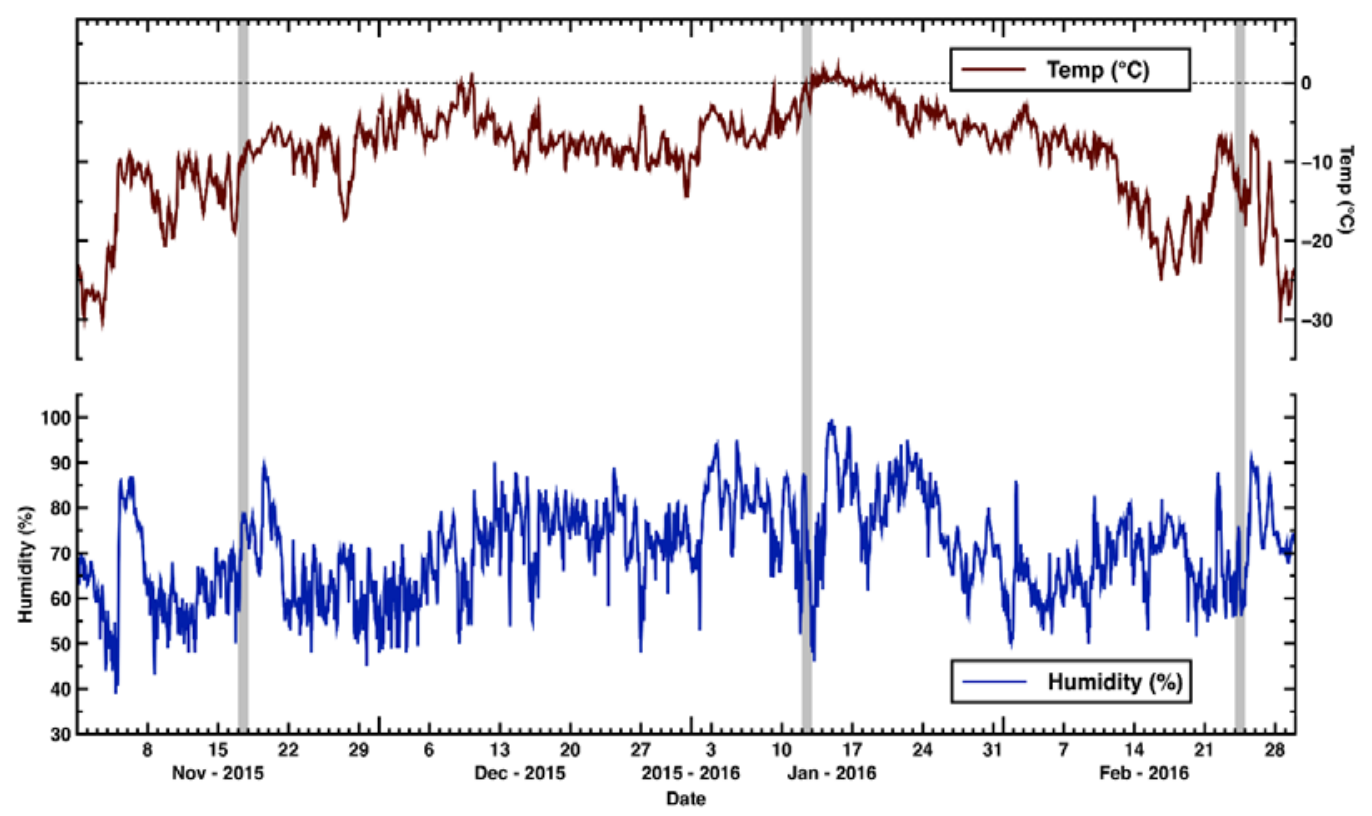


Figure 20. Prevailing wind from a cardinal direction of $145^{\circ}$ with an average speed of $9.6 \mathrm{~m} \mathrm{~s}^{-1}$.

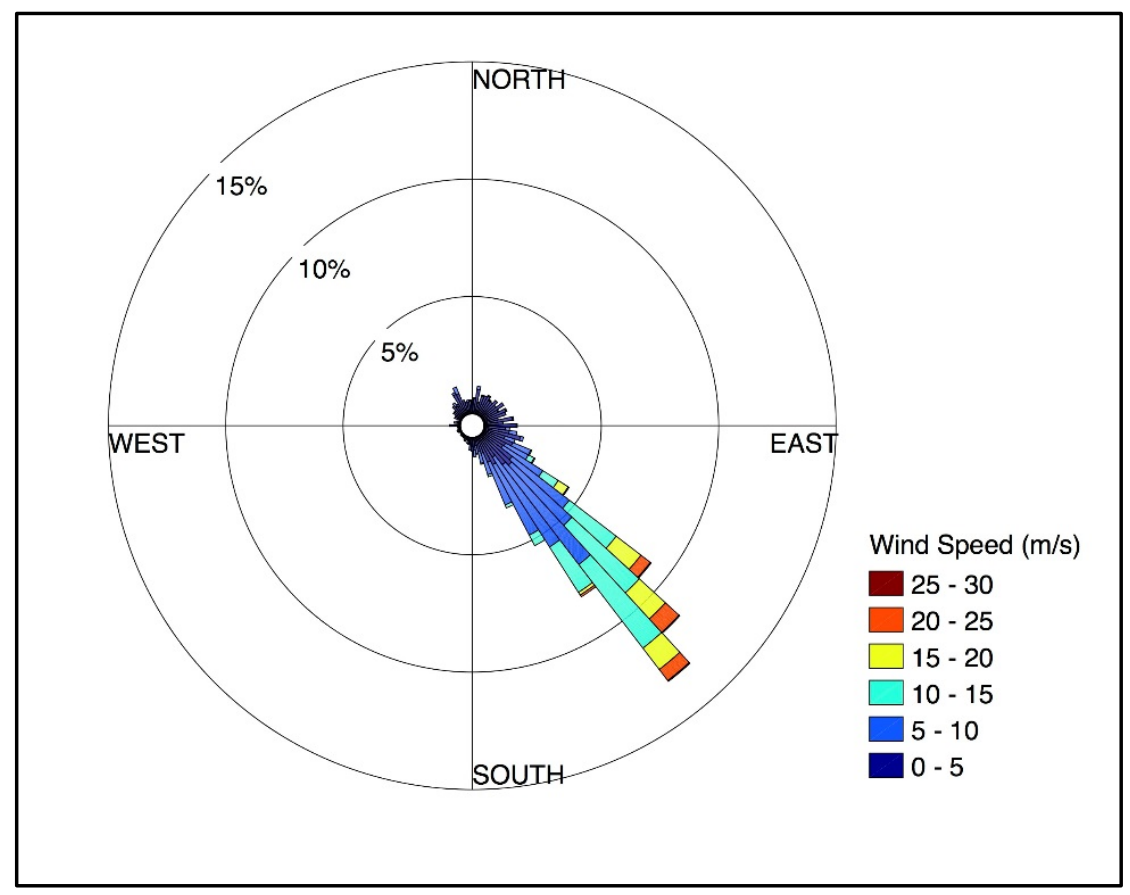

Based on the full suite of data analyzed here, I also suggest that there may be erratic and discontinuous sliding at the bed of Leverett Glacier due to a possible bedrock asperity or "sticky spot." These types of features are common under ice streams, particularly below the major Antarctic Ice Streams and in proximity to the Transantarctic Mountains (Anandakrishnan and Alley 1994, 1997). Ice-stream "sticky spots" can have enormous impact on overall ice velocity and stagnation, micro-seismic and crevassing behavior, basal friction and slide potential, and water piracy of other nearby major ice streams (Alley 1993; Stokes et al. 2007; MacAyeal et al. 1995). Again, a more-detailed investigation involving ground-based surveys would be necessary to adequately test this hypothesis.

I also attempted to complete a basic numerical investigation of surface crevasse propagation by using a viscoelastic constitutive damage model (Duddu et al. 2013). I was not successful, however, in making any confident determinations because of both the limited available data and the fairly consistent and uniform behavior of the primary crevasse over the 5 years in this study. In their recent study, Duddu et al. (2013) suggest that crevasses can propagate deeper than those predicted by the Nye zerostress model, therefore illustrating the dominant role of creep damage (fracture) evolution. Crevasses are driven by tensile stress generated by the cryostatic stress-induced creep flow that varies with the depth (Nye 1957; 
Weertman 1964), assuming a viscous strain component given by Glen's flow law (Glen 1955) and established creep-damage power-law evolution equations (Kachanov 1958). As an initial crevasse propagates deeper, the variation of the horizontal creep flow velocity decreases, and therefore the tensile stress driving crevasse propagation decreases as well. However, even in the case of dry, thick glaciers, Duddu et al. (2013) found that water-free surface crevasses do not propagate anywhere near the full glacier thickness. This would seem to indicate in the case of Leverett Glacier that the crevasse does not propagate the necessary $1000 \mathrm{~m}$ to reach the bed; however, they did also find that surface crevasses propagate to greater depths when they are located at a distance more than one ice slab thickness from the grounding line (which is the case for the primary crevasse on Leverett Glacier).

Duddu et al. (2013) also found that crevasses form closer to the terminus of a glacier when the base is fixed to the bedrock (i.e., no basal slip at the bed of the glacier). Considering the proximity of the primary crevasse to the grounding line, this finding may help to corroborate the hypothesis of a possible bedrock feature, like an asperity, preventing consistent basal slide (in addition to the aforementioned possibility of tidal influence on the grounding line of the glacier).

It is important to note that in their simulations, Duddu et al. (2013) assume non-realistic and idealized boundary conditions and glacier geometries. Because the primary crevasse investigated here showed little-to-no evolution over the 5-year span covered with the available imagery, I concluded that this ice-flow crevasse propagation model is insufficient at making any confident determinations or predictions for the major crevasse along the SPoT route. 


\section{Recommendation}

As stated in section 1.2, ultimately the aim of this study was to address several questions regarding this recently discovered crevasse at the base of Leverett Glacier along the SPoT route and to provide recommendations for the route. I determined over the 5-year period investigated here, that the primary crevasse is not significantly growing or migrating closer to the route and thereby does not pose an immediate danger to the crew, vehicles, or equipment. Additionally, I concluded that the existing crevasse propagation model applicable to this study is insufficient at making any confident determinations or predictions for this major crevasse. Hopefully, more advanced crevasse propagation modeling will be developed and tested in the future that may yield better predictions for these types of scenarios.

With this said, however, there is one proactive recommendation for future South Pole Traverses as a result of this study-a single 1- $2 \mathrm{~km}$ deflection (Figure 21) to a new GPS waypoint off the existing route.

Figure 21. Recommended SPoT reroute shown overlaid on Fig. 8. This reroute involves a single 1-2 km deflection to a new GPS waypoint off the existing route, thus adding a continuous $1 \mathrm{~km}$ safe "buffer space" on all sides.

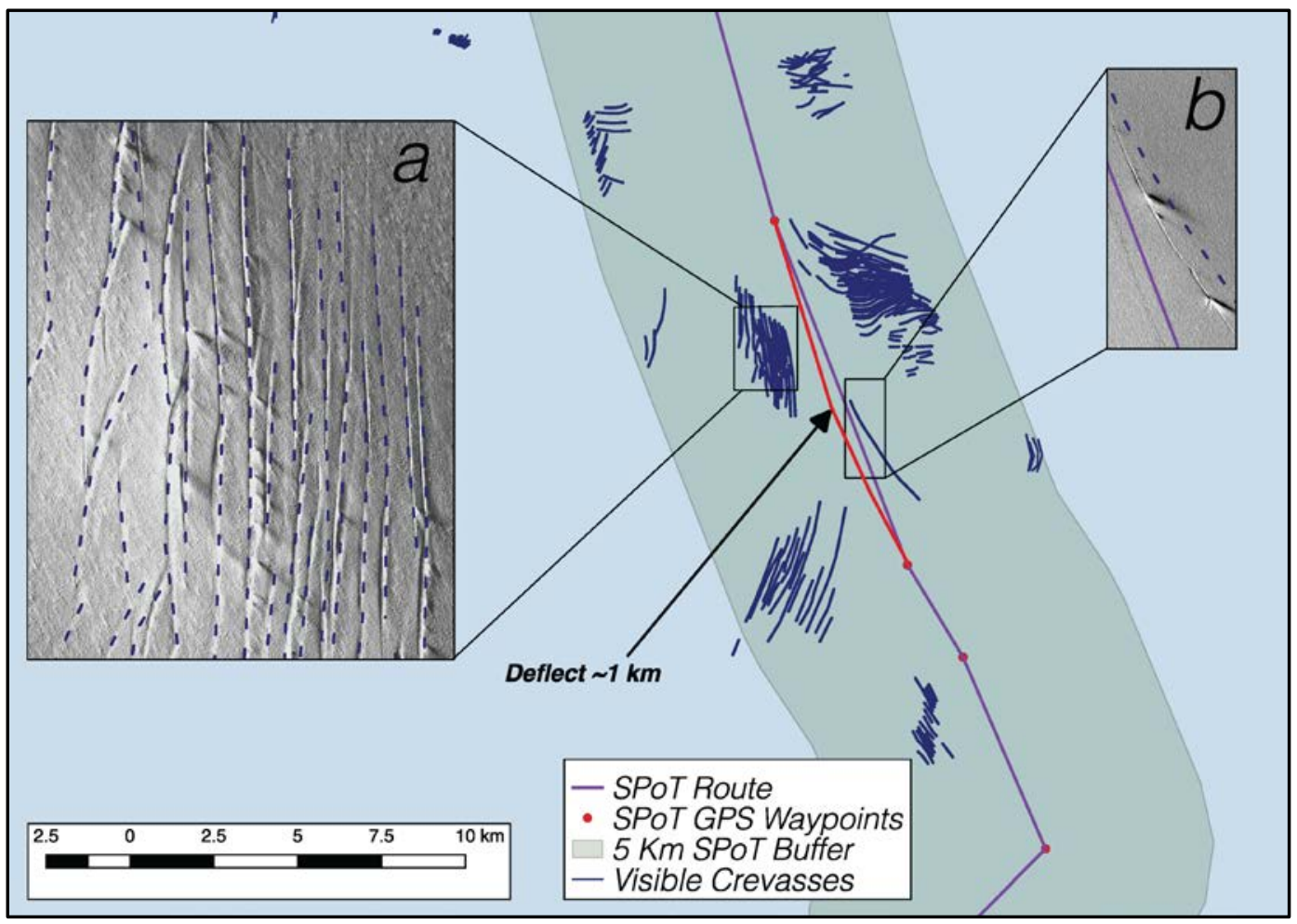


This deflection would thus add a continuous $1 \mathrm{~km}$ safe "buffer space" on all sides through the most heavily crevassed and potentially hazardous part of the SPoT route. Upon arrival at the newly deflected GPS waypoint, the SPoT caravan would then return to the next existing and established GPS waypoint before finally continuing on the remainder of the existing route through to South Pole.

Ultimately, I also propose a more robust investigation involving a suite of additional satellite radar imagery and ground-based surveys to create a more-detailed crevasse hazard assessment along Leverett Glacier portion of the SPoT route. Particularly, I recommend that a new series of GPS stake measurements be made along the route to better constrain higherresolution estimates of mean ice velocity on Leverett Glacier. Lastly, I also recommend dedicating a full day for the SPoT personnel to perform necessary measurements (particularly the extensive radar and GPS stake surveys) during one of the traverses. As previously stated, regardless of the findings of this study, I recommend continued vigilance and proactive hazard awareness during every SPoT through the use of active real-time (ground-based) radar surveys. 


\section{Conclusion}

USAP operates multiple yearly supply traverses (SPoT) between McMurdo Station and Amundsen-Scott South Pole Station. These traverses cover more than 1600 continuous kilometers during each one-way journey (3200 km round-trip). Recent assessments have determined that these traverses not only deliver several hundred thousand pounds of muchneeded fuel and supplies to the South Pole Station but also yield an economic benefit through the offsetting of LC- 130 fuel tanker aircraft flights. Additionally, each traverse reduces annual $\mathrm{CO}_{2}$ emissions associated with Antarctic fuel transport (by over 50\%) and increases the availability of overcommitted on-continent LC-130 aircraft for other critical science project support. Maintaining an active annual SPoT campaign for the purposes of fuel and cargo delivery to the Amundsen-Scott South Pole Station is thus an economic and practical necessity to the USAP, provided that it remains safe for both personnel and equipment.

Through the investigation of various satellite and ground-based data sets (including multispectral satellite imagery, radar and ice-velocity data, and meteorological weather-station data), this report presents a full assessment covering the safety and potential hazards along the crevassed area of the SPoT route, with a specific focus on the heavily crevassed region near the base of Leverett Glacier. I focused on one crevasse in particular that the SPoT caravan encountered in 2013 and evaluated it in higher detail across multiple available high-resolution data sets to discern any potential hazardous growth, migration, or evolution that might warrant alterations to the existing SPoT route.

Overall, I determined the SPoT route to be safe; however, a course reroute that involves a single 1-2 km deflection to a new GPS waypoint off the existing route would add a $1 \mathrm{~km}$ safe "buffer space" on both sides of the existing SPoT route. Additionally, I recommend a more robust investigation involving supplemental radar imagery and ground-based surveys and ground-based GPS velocity stake measurements. Lastly, continued vigilance and proactive hazard awareness is always essential during every South Pole traverse by using active real-time (ground-based) radar surveys. 


\section{References}

Alley, R. B. 1993. In Search of Ice-Stream Sticky Spots. J ournal of Glaciology 39 (133): 447- 454 .

Anandakrishnan, S., and R. B. Alley. 1994. Ice Stream C, Antarctica, Sticky Spots Detected by Micro-Earthquake Monitoring. Annals of Glaciology 20 (1): 183186.

_ 1997. Stagnation of Ice Stream C, West Antarctica by Water Piracy. Geophysical Research Letters 24 (3): 265- 268.

Bamber, J . L., J . L. Gomez-Dans, and J . A. Griggs. 2009. A New 1 km Digital Elevation Model of the Antarctic Derived from Combined Satellite Radar and Laser Data Part 1: Data and Methods. The Cryosphere 3:101-111.

Blaisdell, G. L., and D. Bresnahan. 2000. Analysis of McMurdo to South Pole Traverse as a Means to Increase LC-130 Availability in the USAP. In Proceedings of the NSFOPP Workshop on Enhanced Airlift Options, Washington, DC.

Blaisdell, G. L., P. W. Richmond, F. C. Kaiser, and R. G. Alger. 1997. Development of a Modern Heavy-Haul Traverse for Antarctica. In Proceedings of the 7th International Offshore and Polar Engineering Conference, Honolulu, 2:529536.

Duddu, R., J . N. Bassis, and H. Waisman. 2013. A Numerical Investigation of Surface Crevasse Propagation in Glaciers Using Nonlocal Continuum Damage Mechanics. Geophysical Research Letters 40 (12): 3064- 3068.

Fretwell, P., H. D. Pritchard, D. G. Vaughan, J . L. Bamber, N. E. Barrand, R. Bell, C. Bianchi, R. G. Bingham, D. D. Blankenship, G. Casassa, and G. Catania. 2013. Bedmap2: Improved Ice Bed, Surface and Thickness Datasets for Antarctica. The Cryosphere 7:375- 393.

Glen, J . W. 1955. The Creep of Polycrystalline Ice. In Proceedings of the Royal Society of London A: Mathematical, Physical, and Engineering Sciences 228 (1175): 519538.

Griggs, J . A., and J . L. Bamber. 2009. A New 1 km Digital Elevation Model of Antarctica Derived from Combined Radar and Laser Data Part 2: Validation and Error Estimates. The Cryosphere 3:113- 123.

Kachanov, L. M. 1958. Time of the Rupture Process under Creep Conditions. Izvestiya Akademii Nauk SSSR. Otdelenie Teckhnicheskikh Nauk 8 (1): 26- 31.

Lazzara, M. A., G. A. Weidner, L. M. Keller, J . E. Thom, and J . J . Cassano. 2012. Antarctic Automatic Weather Station Program: 30 Years of Polar Observation. Bulletin of the American Meteorological Society 93 (10): 1519- 1537.

Lever, J . H., and P. Thur. 2014. Economic Analysis of the South Pole Traverse. ERDC/CRREL TR-14-7. Hanover, NH: Engineer Research and Development Center. 
MacAyeal, D. R., R. A. Bindschadler, and T. A. Scambos. 1995. Basal Friction of Ice Stream E, West Antarctica. J ournal of Glaciology 41 (138): 247- 262.

Minchew, B. M., M. Simons, B. Riel, and P. Milillo. 2017. Tidally Induced Variations in Vertical and Horizontal Motion on Rutford Ice Stream, West Antarctica, Inferred from Remotely Sensed Observations. J ournal of Geophysical Research: Earth Surface 122:167- 190.

Nye, J . 1957. The Distribution of Stress and Velocity in Glaciers and Ice Sheets. In Proceedings of the Royal Society of London A 239 (1216): 113- 133.

Pearson, F. 1990. Map Projections: Theory and Applications. Boca Raton, FL: CRC Press.

Rignot, E., J . Mouginot, and B. Scheuchl. 2011a. Antarctic Grounding Line Mapping from Differential Satellite Radar Interferometry. Geophysical Research Letters 38: L1054.

— 2011b. Ice Flow of the Antarctic Ice Sheet. Science 333 (6048): 1427- 1430. doi: 10.1126/ science.1208336.

— 2011c. MEaSUREs InSAR-Based Antarctica Ice Velocity Map, Version 1. Boulder, Colorado: NASA National Snow and Ice Data Center Distributed Active Archive Center.

Short, N. H., and A. L. Gray. 2004. Potential for RADARSAT-2 Interferometry: Glacier Monitoring Using Speckle Tracking. Canadian J ournal of Remote Sensing 30 (3): 504- 509.

Snyder, J . P. 1987. Map Projections-A Working Manual. U.S. Geological Survey Professional Paper 1395. Washington, DC: U.S. Government Printing Office.

Stokes, C. R., C. D. Clark, O. B. Lian, and S. Tulaczyk. 2007. Ice Stream Sticky Spots: A Review of Their Identification and Influence Beneath Contemporary and PalaeoIce Streams. Earth-Science Reviews 81 (3): 217- 249.

Weale, J ., and J . H. Lever. 2008. Innovations in Over-Snow Cargo Transport. Cold Regions Science and Technology 52 (2): 166- 176.

Weertman, J . 1964. Glacier Sliding. Research Report 162. Hanover, NH: Cold Regions Research and Engineering Laboratory. 


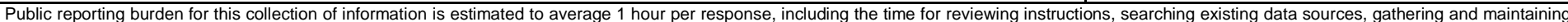

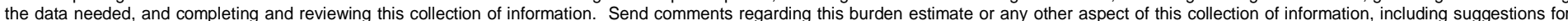

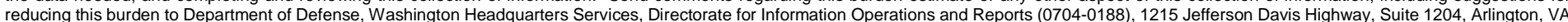

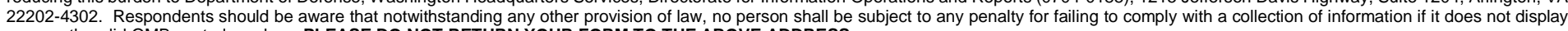
a currently valid OMB control number. PLEASE DO NOT RETURN YOUR FORM TO THE ABOVE ADDRESS.
1. REPORT DATE (DD-MM-YYYY) 2. REPORT TYPE
October 2017
Technical Report/Final

\section{TITLE AND SUBTITLE}

The Potential Risks and Future Impact of a Large Leverett Glacier Crevasse along the South Pole Traverse (SPoT)

3. DATES COVERED (From - To)

5a. CONTRACT NUMBER

5b. GRANT NUMBER

5c. PROGRAM ELEMENT NUMBER

\section{AUTHOR(S)}

John M. Fegyveresi

\section{5d. PROJECT NUMBER}

5e. TASK NUMBER

EP-ANT-16-26

5f. WORK UNIT NUMBER

\section{PERFORMING ORGANIZATION NAME(S) AND ADDRESS(ES)}

\section{PERFORMING ORGANIZATION REPORT} NUMBER

U.S. Army Engineer Research and Development Center (ERDC)

Cold Regions Research and Engineering Laboratory (CRREL)

ERDC/CRREL TR-17-16

72 Lyme Road

Hanover, NH 03755-1290

\section{SPONSORING / MONITORING AGENCY NAME(S) AND ADDRESS(ES)}

National Science Foundation, Office of Polar Programs

Antarctic Infrastructure and Logistics

2415 Eisenhower Avenue

Alexandria, VA 22314

10. SPONSOR/MONITOR'S ACRONYM(S)

NSF

11. SPONSOR/MONITOR'S REPORT NUMBER(S)

\section{DISTRIBUTION / AVAILABILITY STATEMENT}

Approved for public release; distribution is unlimited.

\section{SUPPLEMENTARY NOTES}

Engineering for Polar Operations, Logistics, and Research (EPOLAR)

\section{ABSTRACT}

In December 2013, the inbound South Pole Traverse (SPoT) encountered a large (approximately $15 \mathrm{~m} \times 4 \mathrm{~km}$ ) open crevasse at the bottom of Leverett Glacier near the traverse route. A crevasse of this size so close to the traverse route could impede future traverses, resulting in significant delays or reroutes, and could pose a significant safety hazard to the SPoT personnel, vehicles, and equipment should it grow or migrate. These risks are difficult to quantify as the glaciological and meteorological setting around Leverett Glacier is particularly dynamic. The uncertainty estimates associated with the possible future growth of the crevasse are thus not well constrained.

This report presents a compiled time-series analysis of satellite-derived multispectral imagery, satellite-derived ice-velocity data, and ground-based meteorological data in an effort to determine the timing and dynamics related to the appearance, growth, and migration of this crevasse. Though this study determined that the potential hazard posed by this crevasse is minimal to the existing SPoT route and personnel, the author recommends for future traverses a small $(1 \mathrm{~km})$ course reroute correction, new ground-based radar and global positioning system (GPS) surveys, and continued vigilance and proactive hazard awareness with active real-time surveys.

\section{SUBJECT TERMS}

Antarctic Ice Stream Behavior, Antarctica, Crevasse Hazards, Crevasse Propagation, EPOLAR, Glacial crevasses, Glacier Dynamics, Leverett Glacier, Leverett Glacier Crevasse, NSF, South Pole Traverse, SPoT Safety, Traverse Hazard Assessment

\section{SECURITY CLASSIFICATION OF:}

\section{a. REPORT}

Unclassified

\section{b. ABSTRACT}

Unclassified

\section{c. THIS PAGE}

Unclassified
17. LIMITATION OF ABSTRACT

SAR

\section{NUMBER OF PAGES}

38 19a. NAME OF RESPONSIBLE PERSON

19b. TELEPHONE NUMBER (include area code) 